\title{
Uspostava veza Međunarodnoga odbora Crvenoga križa i Narodnooslobodilačke vojske i partizanskih odreda Jugoslavije za vrijeme Drugoga svjetskog rata
}

\author{
MARIO KEVO \\ Hrvatsko katoličko sveučilište \\ Zagreb, Hrvatska \\ mario.kevo@unicath.hr
}

Djelatna uloga Međunarodnoga odbora Crvenoga križa (MOCK) do izražaja dolazi u ratnim okolnostima u provođenju aktivnosti utemeljenih na međunarodnom ratnom pravu da bi se osigurala pomoć za sve ratne stradalnike. U osiguravanju uvjeta rada tijekom Drugoga svjetskog rata MOCK je pokušao uspostaviti službene odnose sa svim zaraćenim državama, odnosno svim vojnim snagama bez obzira na to je li im bio priznat status zaraćene strane. Stoga su u radu prikazani i napori koje je MOCK uložio u pokušaje da pripadnici Narodnooslobodilačke vojske i partizanskih odreda Jugoslavije steknu službeni položaj zaraćene strane, odnosno službeni status ratnih zarobljenika, te da se na njih dosljedno primijene odredbe međunarodnoga ratnog prava. Usprkos prethodnim kontaktima MOCK je tek nakon imenovanja stalnoga predstavnika u Nezavisnoj Državi Hrvatskoj (1943.) započeo opsežne aktivnosti u korist pripadnika partizanskoga pokreta Jugoslavije, od kojih su najvažnije bile praktična primjena odredaba međunarodnoga ratnog prava na zarobljene pripadnike partizanskih jedinica te osiguravanje raznih oblika pomoći. S istom je nakanom predstavnik MOCK-a uspostavio kontakt i s Vrhovnim štabom Narodnooslobodilačke vojske i partizanskih odreda Jugoslavije, a suradnja je olakšana tek nakon potpisivanja sporazuma Tito-Šubašić, što je rezultiralo uspostavom službenih odnosa krajem 1944. godine. Na temelju izvornoga arhivskoga gradiva, objavljenih izvora i literature autor pokazuje i neke aspekte suradnje do završetka rata te u neposrednom poraću.

Ključne riječi: Drugi svjetski rat; Međunarodni odbor Crvenoga križa (MOCK); Jugoslavija; Nezavisna Država Hrvatska (NDH); Narodnooslobodilački pokret; Narodnooslobodilačka vojska i partizanski odredi Jugoslavije.

* Članak je nastao u sklopu istraživačkoga projekta Hrvatskoga instituta za povijest Rat, žrtve, nasilje i granice slobode u hrvatskoj povijesti 20. stoljeća (IP-2019-04-6673), koji financira Hrvatska zaklada za znanost. 


\section{Uvodne napomene}

Djelatna uloga Međunarodnoga odbora Crvenoga križa (MOCK) osobito je bila izražena u ratnim okolnostima, kada do izražaja dolazi rad organizacije u korist svih kategorija ratnih stradalnika, što se prvenstveno odnosilo na pomaganje bolesnim i ranjenim pripadnicima vojnih snaga bez obzira na njihovu pripadnost bilo kojoj zaraćenoj strani te ulogu nepristranoga posrednika i zaštitne snage ratnih zarobljenika. ${ }^{1}$ Ta se iznimno opsežna djelatnost temeljila na normiranom i kodificiranom međunarodnom ratnom pravu, tj. propisanim odredbama Ženevskih i Haaških konvencija, koje je uobličavano od 1864. do 1929. godine. ${ }^{2}$ U procesu kodifikacije običajnoga ratnog prava važni su dokumenti potpisani 29. srpnja 1929. - Ženevska konvencija o poboljšanju položaja ranjenih i bolesnih pripadnika zaraćenih strana na bojnom polju i Ženevska konvencija o postupanju s ratnim zarobljenicima, a potonjom su dopunjene Haaške konvencije (1899., 1907.), čime je utvrđen položaj ratnih zarobljenika te su standardizirane norme i regulirani zakoni i običaji kopnenoga ratovanja. ${ }^{3} \mathrm{U}$ korist stradalnika MOCK je djelovao na načelima nepristranosti i neovisnosti te ravnopravnosti nacionalnih društava Crvenoga križa u svrhu zaštite ljudskih vrijednosti i dostojanstva pripadnika oružanih snaga zaraćenih strana. ${ }^{4}$

Napadom oružanih snaga Njemačkoga Reicha na Poljsku te ulaskom u rat Francuske i Ujedinjenoga Kraljevstva početkom rujna 1939. počeo je Drugi svjetski rat. Odmah po izbijanju rata Kraljevina Jugoslavija zauzela je poziciju neutralnosti, a te napore jugoslavenske vanjske politike osujetio je državni udar izveden krajem ožujka 1941., nakon čega je napadom sila Osovine 6. travnja 1941. i na ovim prostorima započeo Drugi svjetski rat. Kratkotrajni sukob okončan je kapitulacijom jugoslavenske kraljevske vojske sredinom travnja $1941 .^{5}$ Jugoslavenski državni vrh napustio je zemlju, a odredi Dragoljuba Mihailovića, sastavljeni većinom od Srba i Crnogoraca, djeluju kao Jugoslovenska vojska u otadžbini, iako je de facto jedina protuosovinska snaga

1 O ulozi za vrijeme rata usp. HUBER, Principles and Foundations; BUGNION, The International Committee of the Red Cross, 167-243; KEVO, „Neki aspekti rada Središnje agencije za ratne zarobljenike", 651-678.

2 Sažeto o procesu kodifikacije: KEVO, HERMAN KAURIĆ, „Ženevske i Haaške konvencije u teoriji i praksi", 311-320. Usp. BROWN SCOTT, The Hague Conventions and Declarations of 1899 and 1907. O Ženevskim konvencijama usp. BROWN SCOTT, The Geneva Convention of 1906.

3 Convention de Genève du 27 juillet 1929 pour l'amélioration du sort des blessés et des malades dans les armées en campagne i Convention conclue à Genève le 27 juillet 1929 et relative au traitement des prisonniers de guerre, u: Les Conventions de Genève de 1929, 3-62; „Geneva Convention Relative to the Treatment of the Prisoners of War“, 119-177.; „Convention Relating to the Treatment of Prisoners of War", 59-91.

4 LEDERMANN, „The International Organization of the Red Cross”, 636. O radu tijekom Drugoga svjetskog rata usp. Inter Arma Caritas; Report of the International Committee of the Red Cross, vol. I; DJUROVIĆ, The Central Tracing Agency.

5 O podjeli jugoslavenskoga teritorija usp. BOBAN, Hrvatske granice 1918-1993, 45-49. 
u zemlji ostala Komunistička partija Jugoslavije predvođena Josipom Brozom Titom, koja je počela s osnivanjem partizanskih odreda.

Nakon izbijanja oružanoga sukoba vodstvo Međunarodnoga odbora iz Ženeve ponudilo je zaraćenim stranama pomoć u skladu sa svojom ulogom u oružanim sukobima, koja se svodila na pomaganje zdravstvenom osoblju, ratnim zarobljenicima i ranjenim i bolesnim pripadnicima oružanih snaga zaraćenih strana. Aktivnost za osobe ugrožene ratnim okolnostima kanalizirana je preko Središnje agencije za ratne zarobljenike (Agence Centrale des Prisonniers de Guerre du CICR), koja je s radom započela 14. rujna 1939., a čije su službe prikupljale podatke o ratnim zarobljenicima i interniranim civilima, posredovale između zaraćenih strana (poštanske pošiljke, brzojavi) te vodile korespondenciju informativnoga karaktera (prikupljanje podataka, korespondencija s obavještajnim uredima nacionalnih društava Crvenoga križa, korespondencija s obavještajnim uredima koje su za ratne zarobljenike otvarale vlade zaraćenih država). ${ }^{6}$ Iako je međunarodno ratno pravo do izbijanja rata bilo normirano samo za pripadnike oružanih snaga zaraćenih strana (ratni zarobljenici), a na temelju kojega je MOCK bio ovlašten za osnivanje središnjega tijela koje bi se bavilo tom problematikom, Središnja agencija za ratne zarobljenike radila je i u korist civilnih stradalnika, raseljenih osoba, političkih zatvorenika i žrtava rasnih progona. ${ }^{7}$ Nadležnost za te poslove na teritoriju predratne Jugoslavije imala je Jugoslavenska služba (Service yougoslave) Agencije. Istodobno je vodstvo MOCK-a zatražilo da zaraćene države otvore nacionalne obavještajne urede (Bureaux de renseignement) koji bi održavali vezu sa Središnjom agencijom za ratne zarobljenike, a obveza je proizlazila iz 3. i 4. članka Ženevske konvencije o poboljšanju položaja ranjenih i bolesnih pripadnika oružanih snaga na bojnom polju te 77. i 79. članka Ženevske konvencije o postupanju s ratnim zarobljenicima. ${ }^{8}$ Spomenuti obavještajni uredi nisu bili istovjetni uredima koji su otvarani pri upravama nacionalnih društava Crvenoga križa za korespondenciju sa Središnjom agencijom za ratne zarobljenike, a uključivanje sve više zaraćenih strana, odnosno vojnih snaga u sukobu bez obzira na to je li se radilo o službeno priznatim zaraćenim stranama bilo je jedan od temeljnih zadataka MOCK-a da bi se što kvalitetnije pomoglo svim ratnim stradalnicima.

\section{Partisans balkaniques i (ne)službeni kontakti}

Nakon poziva na ustanak pripadnici Komunističke partije Jugoslavije krajem lipnja 1941. počeli su osnivati jedinice Narodnooslobodilačke vojske i partizanskih odreda Jugoslavije (NOV i POJ). Iako su vodstvo i službe MOCK-a prikupljali podatke iz službenih i neslužbenih izvora, od privatnih

6 DJUROVIĆ, The Central Tracing Agency, 108, 111-132.

7 O svim aktivnostima vidi: Report of the International Committee of the Red Cross, vol. II.

8 DJUROVIĆ, The Central Tracing Agency, 78-80. 
osoba kao i dužnosnika država da bi što kvalitetnije obavljali svoju djelatnost, do imenovanja stalnoga predstavnika MOCK-a u Nezavisnoj Državi Hrvatskoj (NDH) početkom veljače 1943. prikupljeni podaci o snagama NOV i POJ (Partisans balkaniques) bili su sporadični i nepouzdani, a tek od proljeća 1943. vodstvo MOCK-a prikuplja preciznije podatke o postojanju još jedne zaraćene strane na području Jugoslavije. ${ }^{9}$ Ozbiljna neinformiranost bila je posljedica jake promidžbe u korist Jugoslovenske vojske u otadžbini koju je provodila izbjeglička jugoslavenska kraljevska vlada, a predstavnici MOCK-a na terenu su se susretali s više nepriznatih organizacija Crvenoga križa, s kojima su surađivali iako su se one međusobno proglašavale nekompetentnima. ${ }^{10}$ Unatoč problemima vodstvo MOCK-a pokušalo je na osnovi načela izbjegavanja konfrontacija i načela reciprociteta uspostaviti kontakte da bi u krug zaraćenih strana koje su poštovale obveze međunarodnoga ratnog prava privuklo što više sukobljenih strana. Iznimka nisu bili ni pripadnici NOV i POJ iako je vodstvo MOCK-a o njima imalo najmanje podataka, pa su službe MOCK-a i predstavnici na terenu djelovali u njihovu korist premda nisu imali izravne kontakte. Bila je to posljedica pokušaja praktične primjene međunarodnoga ratnog prava na zaraćene strane te upotrebe temeljnoga načela reciprociteta kojim je zaraćena strana, bila ona priznata ili ne, osiguravala stupanj primjene međunarodnoga ratnog prava na pripadnike vlastitih postrojbi u skladu sa stupnjem koji je primjenjivala na suprotstavljenu stranu, što je bio jedan od glavnih zadataka MOCK-a koje je pokušao uvesti na terenu. Kako je vrijeme rata prolazilo, snage NOV i POJ sve su više jačale, pa na postojanje takve vojne snage nisu bili imuni Saveznici, ali ni vrh MOCK-a, koji je i iz njemačkih i iz savezničkih izvora te preko Stalnoga predstavništva u Zagrebu dobivao sve više podataka o tome da se radi o respektabilnoj vojnoj sili. ${ }^{11}$

Da bi se stekao potpuni uvid u predmetnu problematiku, najprije treba objasniti položaj koji su pripadnici partizanskoga pokreta uživali u ratnim okolnostima, iz čega su proizašli i prvi kontakti između njih i predstavnika MOCK-a. U Drugom svjetskom ratu postojale su tri kategorije ratnih stradalnika: ratni zarobljenici (Prisonniers de la Guerre - PG), internirani civili (Interné civils - IG) i civili (Civils - C). ${ }^{12}$ Međutim, jedino su ratni zarobljenici uživali zaštitu normiranoga ratnog prava, a stupanj zaštite ovisio je o primjeni

\footnotetext{
$9 \quad$ Narodnooslobodilački pokret, odnosno pripadnici partizanskoga pokreta koji su se sastojali od jedinica Narodnooslobodilačke vojske i partizanskih odreda Jugoslavije, u terminologiji MOCK-a, tj. izvorima na francuskom, njemačkom ili engleskom jeziku, nazivani su partizani (Partisans), balkanski partizani (Partisans balkaniques) ili Titovi partizani (Tito's partisans) da bi se razlikovali od drugih partizanskih pokreta u Europi. Stoga ću u radu koristiti terminologiju korištenu u arhivskim izvorima.

10 CH-ACICR, C G2 YU 39 = G2 YU 1994.0046.00055, Service yougoslave - Organisation du Service, Rapports d'activité, Statistiques, Modèles de fiches. Izvješće o Jugoslavenskoj službi, 11. 2. 1944., 1-2; Revue Internationale de la Croix-Rouge (Genève), XXVI, No. 303, Mars 1944, 246.

11 O jačanju NOV i POJ vidi: DIZDAR, „Brojidbeni pokazatelji odnosa vojničkih postrojbi", 161-197.

12 Report of the International Committee of the Red Cross, vol. II, 52.
} 
načela reciprociteta između zaraćenih strana. Ostale kategorije stradalnika nisu imale reguliranu zaštitu. Internirani civili (IC) bili su građani međusobno zaraćenih država koji su nakon izbijanja rata zatečeni na teritoriju neprijateljske države, pa su stavljeni u zaštitnu internaciju, a u kategoriji civili (C) nalazili su se građani uhićeni u vlastitoj državi iz političkih razloga (politički zatvorenici, komunisti) te žrtve rasnih progona (Židovi, Romi). ${ }^{13}$

Pripadnici partizanskoga pokreta u Jugoslaviji, kao uostalom i partizanske snage u drugim europskim državama, bili su kategorizirani kao „politički zatvorenici” i pripadali su posljednjoj kategoriji ratnih stradalnika, za koje su domicilne vlasti tvrdile da se radi o unutarnjem pitanju svake pojedine države. Iako je vodstvo MOCK-a nakon izbijanja rata započelo akciju da se normirane odredbe $u$ korist ratnih zarobljenika prošire i na internirane civile i civile, vlasti Njemačkoga Reicha to su odbile uz obrazloženje da se radi o civilima (neprijateljskih država) u zaštitnoj internaciji i civilima (uglavnom Židovima) zatvorenima zbog državne sigurnosti te da nisu u nadležnosti oružanih snaga nego političke policije. ${ }^{14}$ I vlasti NDH zauzele su istovjetan stav, a u službenim izvorima i tisku za pripadnike NOV i POJ korišten je izraz „banditi” ${ }^{15}$ Specifičnu situaciju potvrđuju i podaci Jugoslavenske službe Središnje agencije

13 Vodstvo MOCK-a pokrenulo je 20-ih godina XX. stoljeća proces rješavanja položaja civilnoga stanovništva u ratnim okolnostima, a u listopadu 1934. održana je međunarodna diplomatska konferencija Crvenoga križa (Tokio, Japan) na kojoj je dogovoren nacrt sporazuma o reguliranju položaja civilnoga stanovništva iz zaraćenih država (zaštitna internacija). Dokument poznat kao Projekt iz Tokija (Projet de Tokyo) o reguliranju položaja civilnoga stanovništva u ratnim okolnostima označio je početak kodifikacije međunarodnoga ratnog prava za civile (dovršen 1949.). ABPLANALP, „The International Conferences of the Red Cross”, 530-533. Opširnije o kaznenopravnom položaju ratnih zarobljenika uz povijesni pregled usp. JONČIĆ, Ratni zarobljenici, međunarodnopravni status; LOPIČIĆ-JANČIĆ, Krivičnopravna zaštita ratnih zarobljenika u jugoslovenskom krivičnom pravu, 33-176.

${ }_{14}$ CHAPUISAT, Le Comité international de la Croix-Rouge et les déportés, 4-5, 7; CHAPUISAT, Les homes et les faits.

15 O aktivnostima MOCK-a u korist zatočenih civila usp. Documents sur l'activité $d u$ Comité International de la Croix-Rouge; The Work of the ICRC for Civilian Detainees. Više o radu u korist političkih zatvorenika: MOREILLON, Le Comité international de la Croix-Rouge. Izbijanje rata onemogućilo je normiranje položaja civilnoga stanovništva, pa je MOCK pribjegao univerzalnome načelu reciprociteta da se norme Ženevske konvencije iz 1929. o položaju ratnih zarobljenika prošire na internirane civile (zaštitna internacija). Situacija je ovisila od države do države. Primjerice, u Njemačkome Reichu civili su ostali lišeni konvencijske zaštite, a u istovjetnoj situaciji bili su i „politički zatvorenici”. Vodstvo MOCK-a nije dogovorilo sporazum s Njemačkim Reichom o položaju civilnih zatočenika, a vlasti su predstavnicima MOCK-a odbijale odobriti pravo posjeta logorima u koje su internirani civili i žrtve rasnih progona. Tek 1. veljače 1945. ministar vanjskih poslova Reicha obavijestio je MOCK da su vlasti odobrile slanje paketa s pomoći za internirane civile na području Reicha koji su izvorno pristigli s belgijskoga ili francuskoga područja, a 12. ožujka 1945. predsjednik MOCK-a primio je obavijest da Reich dopušta slanje pomoći svim kategorijama zatočenih civila te su odobreni i posjeti logorima na području Njemačkoga Reicha. Prema Ženevskim konvencijama iz 1929., Židovi nisu bili ratni zarobljenici, a spominjani su kao internirani civili iako im nije bio priznat ni taj status. CHAPUISAT, Les homes et les faits; CHAPUISAT, Le Comité international de la CroixRouge et les déportés, 5-6, 8; ABPLANALP, „The International Conferences of the Red Cross”, 532-533; FORSYTHE, „The Red Cross as Transnational Movement”, 612-613, 620. 
za ratne zarobljenike MOCK-a, preko koje su kanalizirane sve djelatnosti u korist ratnih stradalnika, a koja se u prikupljanju podataka i u radu suočila s tim problemom jer su zarobljeni partizani tretirani kao „civili uhvaćeni kao ratni zarobljenici”. ${ }^{16}$ Unatoč nepouzdanim informacijama vodstvo MOCK-a počelo je od boravka posebnoga predstavnika dr. Roberta Schirmera u Zagrebu krajem 1942. stjecati precizniji uvid u problematiku postojanja logora u koje su internirani Srbi, Hrvati i Židovi tretirani kao „politički zatočenici”. ${ }^{17}$

Kako je rečeno, jedan od osnovnih problema u odnosu prema partizanima bila je praktična primjena Ženevskih konvencija. Unatoč nepriznatom statusu zaraćene strane, vodstvo partizanskoga pokreta, vjerojatno nadajući se primjeni načela reciprociteta, od samih je početaka pokušavalo postići proširenje odredaba međunarodnoga ratnog prava i na pripadnike NOV i POJ. O tome svjedoči jedna od prvih naredaba Vrhovnoga štaba Narodnooslobodilačkih partizanskih odreda Jugoslavije o tretiranju zarobljenih pripadnika neprijateljske strane, kojom je Vrhovni štab 8. studenog 1941. upozorio vlastite jedinice da se trebaju „strogo poštovati ratnička pravila”, odnosno da se u odnosu prema zarobljenim pripadnicima neprijateljske strane sve jedinice pridržavaju propisa međunarodnoga ratnog prava. ${ }^{18} \mathrm{Ta}$ jednostrana odluka Vrhovnoga štaba, pod pretpostavkom da su njemačke i vojne snage $\mathrm{NDH}$ uopće znale za njezino postojanje, nije naišla na povoljan odjek, ali je rezultirala preispitivanjem stava u odnosu na zarobljene pripadnike NOV i POJ. Iako su partizani smatrani banditima i političkim zatvorenicima, tj. kategorijama koje nisu uživale zaštitu odredaba međunarodnoga ratnog prava, situacija na terenu daje nešto povoljniju sliku, ali samo kad su u pitanju bili odnosi s njemačkim snagama. Naime, po završetku ofenzive na Kozari sredinom 1942. zarobljeno je mnoštvo stanovništva, a među njima je bilo i pripadnika partizanskoga pokreta. Potvrđuje to i jedno izvješće Ministarstva vanjskih poslova NDH, nastalo oko 1. srpnja 1942., upućeno poglavniku Anti Paveliću. U izvješću je problemom označeno otpremanje muškoga pučanstva u Njemačku, no zanimljivo je da je iskrsnuo problem oko statusa tih osoba jer nije razjašnjeno „imaju li se smatrati radnicima ili zarobljenicima” ${ }^{19}$ Dvojba je zanimljiva ako se promatra u kontekstu međunarodnoga ratnog prava jer se njegove odredbe nisu primjenjivale na (prisilne) radnike, a konvencije o zaštiti civilnoga stanovništva nisu bile potpisane. Stoga je izvješće Ministarstva vanjskih poslova potvrda da se radilo o partizanima, o čijem su se statusu njemačke vojne vlasti dvoumile, ali kako u izvješću stoji da se s njima postupa

16 CH-ACICR, C G2 YU 13 = G2 YU 1994.0046.00013, Rapports divers concernant l'activité du Service 1941-1947. Zabilješka br. 22 Tehničke uprave Središnje agencije za ratne zarobljenike MOCK-a od 14. 1. 1942.

17 CH-ACICR, C G2 YU 39 = G2 YU 1994.0046.00055, Service yougoslave - Organisation du Service, Rapports d'activité, Statistiques, Modèles de fiches. Izvješće o Jugoslavenskoj službi, 11. 2. 1944., 5-6; KEVO, Veze Međunarodnog odbora Crvenog križa i Nezavisne Države Hrvatske, sv. I., 170-171.

18 Prijepis naredbe u: PAVLICA, Sto godina Crvenog križa u Slavonskoj Požegi, 32, 54-55.

19 KISIĆ KOLANOVIĆ, Mladen Lorković. Ministar urotnik, 195. 
kao „s ratnim zarobljenicima”, radilo se o jednom od prvih službenih navoda da su njemačke vojne vlasti sa zarobljenim partizanima postupale u duhu Ženevskih konvencija.

Iduća otegotna okolnost u pokušajima uspostave službenih odnosa sa savezničkim snagama i promjene savezničkoga stava za Vrhovni štab Narodnooslobodilačke partizanske i dobrovoljačke vojske Jugoslavije bila je jaka međunarodna promidžba u korist Jugoslovenske vojske u otadžbini. Stoga su pokušavali uvjeriti Saveznike, prije svega Veliku Britaniju, da su pripadnici jedinica NOV i POJ jedina protuosovinska snaga u zemlji. ${ }^{20} \mathrm{U}$ tom procesu promjene savezničkoga stava važnu ulogu imali su upravo Britanci, koji su u ožujku 1943. odlučili uspostaviti izravni kontakt s predstavnicima maršala Tita. U jeku priprema za iskrcavanje anglo-američkih snaga na Apeninski poluotok 17. travnja 1943. blizu Zvornika (Bosna i Hercegovina) spustila se prva saveznička misija upućena Titu, a nekoliko dana poslije druga misija spustila se kod Brinja u Lici. ${ }^{21}$ Nakon podataka koje su prikupile te misije britanski se stav promijenio, pa Britanci pripadnicima partizanskoga pokreta od sredine 1943. dostavljaju vojnu pomoć iz zraka ili morem. ${ }^{22}$ Nekako istovremeno s britanskim pokušajima da stupe u kontakt s partizanima vodstvo MOCK-a dogovorilo je s nacionalnom organizacijom Crvenoga križa i vlastima NDH postavljanje stalnoga predstavnika MOCK-a u Zagrebu. ${ }^{23}$ Nakon imenovanja Juliusa Schmidlina ml. na mjesto stalnoga predstavnika MOCK se osobito počeo zanimati za "partizansko” pitanje, a Schmidlinov rad svodio se na pokušaje da se partizanima prizna položaj zaraćene strane. Tome su pogodovali i događaji na terenu. Naime, jačanje partizanskoga pokreta i potreba njemačkoga zapovjedništva za angažmanom većih vojnih snaga na području NDH koje bi se borile protiv partizana, ali i gospodarski interesi, nagnali su njemačke vojne zapovjednike da još u kolovozu 1942. krenu u pregovore s partizanima o postizanju sporazuma o razmjeni zarobljenika. ${ }^{24}$ Kako je njemačke vojne vlasti zanimao nastavak opskrbe boksitom iz Livna, započeli su prve pregovore o razmjeni, a partizani su zarobljenicima iz Livna obećali „da će se tretirati kao zarobljenici, sukladno odredbama međunarodnog ratnog prava”. ${ }^{25}$ U skladu s načelom reciprociteta trebali su ostvariti istovjetan položaj. Međutim, o položaju zarobljenih partizana svjedoče otpori Adolfa Hitlera pregovorima s pripadnicima partizanskoga pokreta, o čemu zorno govori i njegova izjava povodom početka tzv. Martovskih pregovora, koje su od 11. ožujka 1943. u Gornjem Vakufu s partizanima vodili njemački vojni zapo-

20 Opširnije o britanskoj politici i odnosu prema zaraćenim stranama na prostoru Kraljevine Jugoslavije za vrijeme rata u: BARKER, Britanska politika na Balkanu, sv. I-II, osobito sv. II, 301 i d. Vidi i: DE SANTIS, „In Search of Yugoslavia”, 541-563.

21 VELEBIT, Sjećanja, 90 i d.

22 BARKER, Britanska politika na Balkanu, sv. I, 120, 150, 161-163.

23 KEVO, „Imenovanje stalnog predstavnika”, 209-234.

24 Opširnije: JOKSIMOVIĆ, „Narodnooslobodilački pokret Jugoslavije kao ratujuća strana i razmena zarobljenika u 1942. godini”, 197-217.

25 Isto, 206. Usp. i: KRIZMAN, Pavelić između Hitlera i Mussolinija, 540-545. 
vjednici. ${ }^{26} \mathrm{Na}$ najavu mogućega sklapanja primirja koju mu je prenio njemački ministar vanjskih poslova Joachim von Ribbentrop Hitler je onemogućio bilo kakav razgovor ustvrdivši da se s pobunjenicima ne pregovara, nego se „oni strijeljaju”. ${ }^{27}$ Ovdje treba dodati i da su se partizani nadali primjeni odredaba međunarodnoga ratnog prava na temelju reciprociteta budući da je prema 1. stavku 1. članka Ženevske konvencije o postupanju s ratnim zarobljenicima djelomično regulirana njihova zaštita, ali nakon što udovolje člancima dodanim IV. Haaškoj konvenciji (1907.) koji su se odnosili na postrojbe koje nisu bile dio regularnih oružanih snaga. ${ }^{28}$ Prema klasifikaciji međunarodnoga ratnog prava, neregularne jedinice bile su milicija i/ili dobrovoljni odredi, a da bi stekli konvencionalnu zaštitu, trebali su se pridržavati čl. 1. Haaških regulacija. ${ }^{29}$ Tim je člancima propisano da se takve osobe moraju nalaziti pod zapovjedništvom odgovornoga zapovjednika, nositi fiksne oznake prepoznatljive na daljinu, otvoreno nositi oružje i pokoravati se zakonima i običajima ratovanja. ${ }^{30}$ Budući da su partizani bili dobrovoljni odredi koji su udovoljavali prethodno navedenim, odnosno propisanim zahtjevima Haaških regulacija, mogli su se smatrati zaštićenom skupinom bez službeno priznatoga statusa regularne oružane snage, čime bi stekli pravo na zaštitu i primjenu ratnoga prava u skladu sa 1. stavkom 1. članka Ženevske konvencije o postupanju s ratnim zarobljenicima, što se pokušavalo dogovoriti u pregovorima s njemačkom stranom.

Istodobno s početkom „Martovskih pregovora” stalni predstavnik Schmidlin angažirao se da se pripadnicima NOV i POJ prizna službeni položaj zaraćene strane. Kako u NDH nije bilo ratnih zarobljenika, primjena odredaba Ženevskih konvencija odnosila se na internirane civile, a u Schmidlinov djelokrug rada ušla je i problematika posljednje kategorije stradalnika (C). Osim toga Schmidlin je trebao poticati poslove iz djelokruga rada Središnje agencije za ratne zarobljenike, prikupljati podatke o logorima te ishoditi mogućnost nesmetane korespondencije ratnih zarobljenika i interniranih civila s obiteljima. Istovremeno je Jugoslavenska služba Središnje agencije za ratne zarobljenike imala ozbiljnih poteškoća sa Središnjim uredom Hrvatskoga Crvenoga križa (HCK), koji je selektivno odgovarao na upite u vezi s civilima, osobito one o civilima zatočenim iz političkih razloga, na koje nije bilo odgovora. ${ }^{31}$ Zbog toga je Schmidlin po povratku iz Švicarske krajem travnja 1943. intervenirao u Pravnom odsjeku Ministarstva vanjskih poslova tražeći

26 Opširnije: LEKOVIĆ, Martovski pregovori 1943., 71 i d. Vidi i: JOKSIMOVIĆ, „Narodnooslobodilački pokret Jugoslavije kao ratujuća strana i razmena zarobljenika u 1943. godini", 95-117; LABOVIĆ, BASTA, Partizani za pregovaračkim stolom.

27 KAZIMIROVIĆ, NDH u svetlu nemačkih dokumenata, 181-182.

28 Les Conventions de Genève de 1929, 20.

$29 \$ 1$. u: Convention (IV) respecting the Laws and Customs of War on Land and its annex, u: BROWN SCOTT, The Hague Conventions and Declarations of 1899 and 1907, 107.

$30 \$ 1 ., \$ 2 ., \$ 3$. u: BROWN SCOTT, The Hague Conventions and Declarations of 1899 and 1907, 107-108; Geneva Conventions for the Protection of War Victims, 5.

31 CH-ACICR, C G2 YU 39 = G2 YU 1994.0046.00055, Service yougoslave - Organisation du Service, Rapports d'activité, Statistiques, Modèles de fiches. Obavijest civilnoga dijela Jugoslavenske službe o suradnji s HCK-om NDH, 23. 3. 1943. 
da Vlada NDH izda deklaraciju o proširenju odredaba o ratnim zarobljenicima i na internirane civile, na što se obvezala krajem 1942. u pregovorima s dr. Schirmerom, posebnim predstavnikom MOCK-a koji je posjetio Zagreb. ${ }^{32}$

\section{Prvi službeni kontakti}

Uslijed promjene britanskoga stava o Titovim partizanima, ali i na temelju podataka koje su dobivali od stalnoga predstavnika u Zagrebu, u vodstvu MOCK-a počeli su ozbiljno razmišljati o uspostavljanju izravnih kontakata s partizanskim predstavnicima. Osim promjene britanskoga stava, bila je to i posljedica saznanja do kojih je vodstvo MOCK-a sasvim slučajno došlo u ljeto 1943. godine. Na temelju prikupljenih podataka MOCK je doznao da se u njemačkim koncentracijskim logorima u okupiranoj Norveškoj nalazi oko 1700 zatočenih Jugoslavena, koji su tretirani kao politički zatvorenici, a ubrzo se ispostavilo da su to zarobljeni pripadnici NOV i POJ koji su se nalazili na prisilnom radu između Egersunda i Narvika. ${ }^{33}$ Najvjerojatnije se radilo o partizanima zarobljenim nakon operacija na Kozari, koji su odabirani u logorima Jasenovac i Stara Gradiška te preko Zemuna upućivani na prisilni rad u Njemački Reich, Francusku i Norvešku. Premda je MOCK znao za postojanje partizanskoga pokreta, nije bio upoznat s cjelovitom političkom situacijom, osobito stoga što su i Saveznici iskazivali određeni oprez prema pripadnicima Narodnooslobodilačke vojske Jugoslavije, a izbjeglička vlada iz Londona tvrdila je da se protiv sila Osovine bore četnici. Upravo su ti, sasvim slučajno prikupljeni, podaci neosporno potvrdili da se partizani bore protiv sila Osovine, pa je stalni predstavnik u Zagrebu Schmidlin u kolovozu 1943. dobio nalog da s njima što je prije moguće uspostavi izravni kontakt. ${ }^{34}$ Osim toga MOCK je u Norvešku poslao posebnoga predstavnika, koji je utvrdio potrebe zatočenika, odnosno nedostatak toplih odjevnih predmeta, cipela, uniformi i kabanica, a žurno je trebalo dostaviti i živežne namirnice. Stoga je zatočenicima poslana pomoć iz skladišta jugoslavenske robe koju je osigurao Američki Crveni križ, a odlučeno je i da će se jednom mjesečno po zatočeniku distribuirati paket živežnih namirnica. Organizacije iz Kaira osigurale su izvjesne količine hrane (riža, grah, leća), osigurani su odjevni predmeti za ranjene i bolesne, manju pomoć osigurao je Norveški Crveni križ iz Osla, a za svakoga zatočenika iz Narvika osigurana je i dostava 210 cigareta mjesečno. ${ }^{35}$

32 CH-ACICR, G. 6/III, Application convention A-F, $1^{\text {er }}$ Septembre 1942. - 31. 12. 1950. Croatie, Schmidlinova obavijest br. XVI upućena Središnjici MOCK-a u Ženevu, 27. 4. 1943.; CH-ACICR, C G2 YU 39 = G2 YU 1994.0046.00055, Service yougoslave - Organisation du Service, Rapports d'activité, Statistiques, Modèles de fiches. Obavijest civilnoga dijela Jugoslavenske službe o suradnji s HCK-om NDH, 23. 3. 1943.; KEVO, Veze Međunarodnog odbora Crvenog križa i Nezavisne Države Hrvatske, sv. I., 38-41.

33 Rapport du Comité International de la Croix-Rouge, vol. III, 285-286.

34 CH-ACICR, G. 17/00/139, Fasc. G. 1700-6.2 = G. 17/00 III, Généralité, Mémorandum au Gouvernement Yougoslave, 4. 3. 1947., 34.

35 Rapport du Comité International de la Croix-Rouge, vol. III, 286. 
Schmidlin je ubrzo stupio u kontakt s Vrhovnim štabom Narodnooslobodilačke partizanske i dobrovoljačke vojske Jugoslavije, a u rujnu 1943. dobio je pozitivan odgovor na upit hoće li Vrhovni štab priznati odredbe Ženevskih konvencija iz 1929., odnosno pridržavati se propisanih normi međunarodnoga ratnog prava. ${ }^{36}$ Premda partizanima nije bio priznat službeni položaj zaraćene strane, aktivnost MOCK-a, kanalizirana preko stalnoga predstavnika u Zagrebu, zasnivala se na drugom temeljnom načelu rada, koje je propisivalo da MOCK ima kooperativan pristup vladama svih država, odnosno svim sukobljenim stranama, te da izbjegava konfrontaciju s njima. ${ }^{37}$ Uspostava de facto odnosa s pripadnicima partizanskoga pokreta bila je izgledna, a radilo se o postavkama na temelju kojih je MOCK uspostavio odnose i s nacionalnim društvom Crvenoga križa i vlastima NDH. Usporedno s koracima poduzetim za ostvarivanje kontakata s pripadnicima NOV i POJ Schmidlin je u rujnu i listopadu 1943. više puta intervenirao u ministarstvima unutarnjih i vanjskih poslova NDH iznoseći zahtjeve, postavljene još u svibnju i lipnju, da se prihvate obveze koje je krajem 1942. preuzeo ministar vanjskih poslova Mladen Lorković, odnosno da se praktična primjena odredaba Ženevskih konvencija proširi i na internirane civile, ali je istodobno tražio i da se zarobljenim partizanima službeno prizna položaj ratnih zarobljenika. ${ }^{38}$ Zahtjeve je početkom listopada pismeno uputio i Ministarstvu oružanih snaga NDH, ali nije dobio nikakav odgovor. ${ }^{39}$ U skladu sa Schmidlinovim zahtjevima, 5. studenog 1943. opsežno pismo ministru vanjskih poslova NDH, podsjećajući na preuzete obveze, uputio je i dr. Frédéric Barbey, visokopozicionirani član MOCK-a. ${ }^{40}$ Schmidlin je glede toga razgovarao s više osoba, uključujući i zagrebačkoga nadbiskupa Alojzija Stepinca, ne bi li utjecale na vlasti NDH da se pridržavaju preuzetih obveza. U osobnim i pismenim intervencijama tražio je i da Ministarstvo unutarnjih poslova NDH dostavi popis logora i poimenične popise zatočenika te da izda nužna odobrenja za posjet logorima i slanje pomoći zatočenicima, na što je primio negativan odgovor uz obrazloženje da su to poslovi iz djelokruga rada HCK-a. ${ }^{41}$ Međutim, čini se da su Schmidlinovi kontakti s viđenijim osobama javnoga i političkoga života imali izvjesnoga uspjeha budući da je ubrzo primio posebnu deklaraciju kojom su se vlasti obvezale otvoriti Obavještajni ured za ratne zarobljenike, a tek 31. siječnja 1944. Vlada NDH izdala je pismenu suglasnost za proširenje odredaba Ženevskih

36 CH-ACICR, G. 17/00/139, Fasc. G. 1700-6.2 = G. 17/00 III, Généralité, Mémorandum au Gouvernement Yougoslave, 4. 3. 1947., 34.

37 FORSYTHE, „The Red Cross as Transnational Movement”, 613.

38 CH-ACICR, G. 6/III, Application convention A-F, $1^{\text {er }}$ Septembre 1942. - 31. 12. 1950., Croatie. Schmidlinove obavijesti (br. 172, br. 214) Središnjoj agenciji za ratne zarobljenike MOCK-a, 13. 9. 1943., 13. 10. 1943.

39 CH-ACICR, G. 6/III, Application convention A-F, $1^{\text {er }}$ Septembre 1942. - 31. 12. 1950. Croatie. Schmidlinove obavijesti br. 214, 13. 10. 1943., 2.

${ }^{40}$ CH-ACICR, G. 85/Croatie. Pismo F. Barbeya Ministarstvu vanjskih poslova NDH, 5. 11. 1943.

${ }^{41}$ CH-ACICR, G. 3/00, Rapports généraux des délégations, Croatie - J. Schmidlin, Obavijest br. 16, 31. 10. 1943., 2-3, Obavijest br. 17, 23. 11. 1943. 
konvencija i na internirane civile. ${ }^{42}$ Ipak, u praksi je sve ostalo isto kao i prije donošenja tih odluka.

U studenome 1943. stalni predstavnik MOCK-a iz Zagreba opet je kontaktirao s Vrhovnim štabom NOV i POJ da bi dobio odgovor na postavljeno pitanje o uspostavi službenih odnosa, a istodobno je uputio više zahtjeva koji su trebali biti pravni temelj realizacije toga procesa, odnosno - kao i u pregovorima s vlastima NDH krajem 1942. - Schmidlin je predložio da Vrhovni štab NOV i POJ prihvati primjenu Ženevske konvencije o postupanju s ratnim zarobljenicima iz 1929. i njezinu primjenu analogijom proširi i na internirane civile te da prihvati stalnoga predstavnika MOCK-a koji će djelovati pri partizanima sa svim pravima prema tradicionalnom djelokrugu radu MOCK-a. Ostali su se zahtjevi odnosili na odobrenje rada u korist Jugoslavenske službe Središnje agencije za ratne zarobljenike MOCK-a, odnosno zatražio je odobrenje da MOCK na oslobođena područja na kojima je vladala glad dostavlja pošiljke pomoći za civilno stanovništvo ugroženo ratnim okolnostima, iako je dostava pomoći bila ograničena savezničkom pomorskom blokadom jer je NDH smatrana neprijateljskom državom. ${ }^{43} \mathrm{U}$ sklopu tih aktivnosti Schmidlin je za vrijeme tih kontakata Vrhovnom štabu NOV i POJ uspio dostaviti i 1250 doza cjepiva protiv pjegavoga tifusa, zatim po dva primjerka obiju Ženevskih konvencija iz 1929., koje je preveo na hrvatski jezik, te više brošura o radu MOCK-a, a Vrhovni štab NOV i POJ zamolio je neka svoje stavove glede iznijetih prijedloga uputi izravno u Ženevu. ${ }^{44}$ Vidljivo je da MOCK nije odustajao od održavanja veza s (ne)službenom zaraćenom stranom, pa je ostvaren kontakt s partizanima na temelju načela kooperativnosti i izbjegavanja konflikata, ali, za razliku od NDH, koja se obratila MOCK-u da bi se uspostavili službeni odnosi, ovdje je bila potpuno suprotna situacija. Iako se radilo o nepriznatoj strani, Schmidlin je očekivao da će doći do uspostave de facto odnosa. U prilog tome razvijala se i međunarodna situacija, a gotovo istovremeno s pregovorima koje je Schmidlin vodio s predstavnicima Vrhovnoga štaba Narodnooslobodilačke vojske Jugoslavije održana je Teheranska konferencija savezničkih vođa, na kojoj su jugoslavenski partizani priznati savezničkom stranom koja je dio antifašističke borbe. ${ }^{45} \mathrm{Ti}$ su događaji ubrzali i postupke MOCK-a, koji je za vrijeme rata pažljivo pratio diplomatske poteze britanske vlade, a već dan nakon početka susreta u Teheranu (29. studenog 1943.) vod-

42 CH-ACICR, G. 17/00/139, Fasc. G. 1700-6.2 = G. 17/00 III, Généralité, Mémorandum au Gouvernement Yougoslave, 4. 3. 1947., 20-21; CH-ACICR, G. 85/Croatie, Dopis (br. 216/1944.) Ministarstva vanjskih poslova NDH upućen Stalnom predstavništvu MOCK-a u Zagrebu, 31. 1. 1944.

43 CH-ACICR, G. 17/00/139, Fasc. G. 1700-6.2 = G. 17/00 III, Généralité, Mémorandum au Gouvernement Yougoslave, 4. 3. 1947., 34-35; KEVO, Veze Međunarodnog odbora Crvenog križa i Nezavisne Države Hrvatske, sv. I., 182-183.

44 CH-ACICR, G. 6/III, Application convention A-F, $1^{\text {er }}$ Septembre 1942. - 31. 12. 1950., Croatie. Nedatirano izvješće o aktivnostima MOCK-a u NDH - Rotkreuz - Propaganda in Kroatien; CH-ACICR, G. 17/00/139, Fasc. G. 1700-6.2 = G. 17/00 III, Généralité, Mémorandum au Gouvernement Yougoslave, 4. 3. 1947., 25, 35.

45 SPEHNJAK, Britanski pogled na Hrvatsku, 27. 
stvu MOCK-a iz Londona je upućena pismena sugestija da započne pregovore o uspostavi službenih odnosa s partizanima. ${ }^{46}$ Budući da je Schmidlin već uspostavio kontakte, u Ženevi su iščekivali odgovor na prijedloge o suradnji, ali Vrhovni štab Narodnooslobodilačke vojske Jugoslavije tek se krajem siječnja 1944. obratio vodstvu MOCK-a. ${ }^{47}$ Predstojalo je održavanje pregovora na kojima su se trebali dogovoriti detalji suradnje, ali predstavnik MOCK-a tek je u svibnju 1944. u Bariju uspio stupiti u kontakt s pukovnikom dr. Nikolom Nikolićem, članom Sanitetskoga odsjeka Vrhovnoga štaba NOV i POJ te šefom Zdravstvenoga odsjeka NOV i POJ u Italiji. Iako ugovoren, planirani sastanak nije održan, pa je predstavnik MOCK-a pukovniku Nikoliću 14. svibnja i 11. lipnja 1944. uputio pisma u kojima je zatražio službeni odgovor u vezi s dostavljenim prijedlozima, ali kako nije bilo odgovora, pregovori o uspostavljanju službenih odnosa bili su obustavljeni. ${ }^{48}$

No, vratimo se pregovorima njemačkih zapovjednika i partizana, koji su usprkos otporu njemačkoga vrha nastavljeni, a partizani su, prema Titovim uputama, trebali težiti postizanju dogovora o razmjeni zarobljenika te o primjeni odredaba međunarodnoga ratnog prava na pripadnike Narodnooslobodilačke vojske na temelju načela reciprociteta. ${ }^{49}$ Njemački ministar vanjskih poslova Ribbentrop upozorio je njemačkoga poslanika u NDH Siegfrieda Kaschea da se ne upušta u pregovore s „banditima”, što je 29. ožujka 1943. potkrijepio brzojavom u kojem je izričito zatražio da se suzdrži od bilo kakva dodira ili pregovora s Titom. ${ }^{50}$ Međutim, nešto prije potpisan je sporazum njemačkih vojnih vlasti u NDH i pripadnika partizanskoga pokreta o razmjeni zarobljenika. ${ }^{51}$ Tim su sporazumom, unatoč protivljenju vlasti NDH, partizani de facto priznati zaraćenom stranom, što je potvrdio i stalni predstavnik Schmidlin u obavijesti upućenoj Središnjici MOCK-a, navodeći da su u rujnu 1943. njemački vojni zapovjednici partizanima priznali takav status. ${ }^{52}$ Do promjene stava došlo je i u Njemačkom Reichu, što potvrđuje i Hitlerova zapovijed iz prosinca 1943. kojom je naredio da se zarobljeni partizani ne strijeljaju, nego tretiraju kao ratni zarobljenici u duhu ratnoga prava. ${ }^{53}$

Unatoč takvoj situaciji Schmidlin je i dalje inzistirao da partizanima položaj službeno priznaju i Nijemci i vlasti u Zagrebu. U povjerljivoj obavijesti koju je 11. travnja 1944. poslao Središnjici u Ženevu navodi da je dobio uvjeravanja dr. Vilka Riegera, šefa Političkoga odsjeka Ministarstva vanjskih

46 CH-ACICR, B SEC DAS ZA-028, Délégation du CICR en Yougoslavie [y compris Croatie] : [correspondance générale], Dopis C. Pillouda, 29. 11. 1943.

47 CH-ACICR, G. 17/00/139, Fasc. G. 1700-6.2 = G. 17/00 III, Généralité, Mémorandum au Gouvernement Yougoslave, 4. 3. 1947., 35.

48 Isto.

49 LEKOVIĆ, Martovski pregovori 1943., 70, 89-90.

50 Isto, 115, 141.

51 BEGIĆ, Nezavisna Država Hrvatska, 131.

52 CH-ACICR, G. 3/00, Rapports généraux des délégations, Croatie - J. Schmidlin, Obavijest br. 14, 1. 10. 1943., 1.

53 KAZIMIROVIĆ, NDH u svetlu nemačkih dokumenata, 131. 
poslova NDH i jednoga „od vodećih ljudi Ustaškog pokreta”, da će s njemačke strane to pitanje biti ubrzo pozitivno riješeno, a slično će postupiti i vlasti $\mathrm{NDH} .{ }^{54}$ MOCK je preko Schmidlina nastavio intervenirati da bi se partizanima priznao položaj zaraćene strane, a još za vrijeme prvih kontakata s njima zatražio je da vlasti NDH konačno otvore Obavještajni ured za ratne zarobljenike u NDH. ${ }^{55}$ Vlasti su to u više navrata obećale učiniti iako su to stalno odgađale, a Ured je naposljetku otvoren 17. lipnja 1944. godine. ${ }^{56}$ Pred otvaranje Ureda Schmidlin je više puta osobno intervenirao kod dr. Tihomila Drezge u Pravnom odsjeku Ministarstva vanjskih poslova NDH da se partizanima de facto prizna „ženevski status ratnih zarobljenika”, za što mu je na raspolaganje stavljen savjetnik u Političkom odjelu Ministarstva vanjskih poslova dr. Ernest Bauer. ${ }^{57}$ U dopisu Središnjoj agenciji za ratne zarobljenike MOCK-a Schmidlin se početkom srpnja 1944. osvrnuo na problematiku na temelju odgovora koji je primio, odnosno „partizansko pitanje” bilo je stavljeno na čekanje jer nije bilo poznato hoće li se partizani pridržavati načela reciprociteta. ${ }^{58}$ Povodom toga Schmidlin je u drugoj polovini 1943. dva puta izravno kontaktirao s Vrhovnim štabom Narodnooslobodilačke vojske Jugoslavije, pozvao na poštovanje odredaba Ženevskih konvencija te na primjenu načela reciprociteta, ali kako nije primio odgovor, zamolio je vodstvo MOCK-a da tome posveti posebnu pozornost. Bitno je ovdje dodati da su vodstvu MOCK-a bile vezane ruke jer njegovi predstavnici na terenu nisu mogli jamčiti njemačkoj strani da će partizani primjenjivati načelo reciprociteta. ${ }^{59}$

Unatoč svim problemima u vodstvu MOCK-a bili su svjesni važnosti „partizanskoga pitanja”, pa je svim zaraćenim državama 17. kolovoza 1944. upućen memorandum o postupanju sa sukobljenom stranom kojoj nisu bila priznata prava i položaj zaraćene strane. ${ }^{60}$ Iako je postojalo više partizanskih pokreta u Europi za vrijeme rata, taj se memorandum odnosio na jugoslavenske partizane, a u njemu je iznova naglašen stav da se osnovna načela ratnoga prava i humanosti trebaju primjenjivati i kad se pojave slučajevi koji nisu jasno navedeni u konvencijama. MOCK je smatrao da se na sve oruža-

54 CH-ACICR, G. 6/III, Application convention A-F, $1^{\text {er }}$ Septembre 1942. - 31. 12. 1950. Croatie. Schmidlinova povjerljiva obavijest br. 475, 11. 4. 1944.

55 CH-ACICR, G. 3/00, Rapports généraux des délégations, Croatie - J. Schmidlin, Obavijest br. 14, 1. 10. 1943., 1, Obavijest br. 6, 26. 6. 1944.

56 CH-ACICR, C G2 YU 45 = G2 YU 1994.0046.00068, Camps. Schmidlinova obavijest (br. 679) upućena MOCK-u u Ženevu, 20. 6. 1944.

57 CH-ACICR, G. 3/00, Rapports généraux des délégations, Croatie - J. Schmidlin, Obavijest br. 6, 26. 6. 1944.; CH-ACICR, G. 6, Application des Conventions, Extension des Conventions, 1939-1950., 6/III, Application convention A-F, $1^{\text {er }}$ Septembre 1942. - 31. 12. 1950., Croatie. Schmidlinova izvješća br. 620 (23. 5. 1944.), br. 653 (6. 6. 1944.), br. 657 (12. 6. 1944.).

58 CH-ACICR, G. 59/2/151 - 15 (6. 7. 1944. - 25. 10. 1944.), Schmidlinov dopis Središnjoj agenciji za ratne zarobljenike MOCK-a, 6. 7. 1944.

${ }_{59}$ CH-ACICR, G. 17/00/139, G. 17/00-6.2 = G. 17/00 III, Mémorandum au Gouvernement yougoslave, 4. 3. 1947., 37.

${ }_{60}$ CH-ACICR, G. 17/00/139, G. 17/00 III, Mémorandum au Gouvernement yougoslave, août 46-mars 48. Memorandum od 17. 8. 1944. 
ne skupine koje se pridržavaju zakona i običaja ratovanja, osobito ako su se nalazile pod zapovjedništvom odgovornoga zapovjednika, imale jasno prepoznatljive oznake i otvoreno nosile oružje, trebalo primijeniti sva jamstva koja su bila zagarantirana ratnim zarobljenicima. ${ }^{61} \mathrm{Iz}$ podnijetoga je obrazloženja očito da je apel nastao na temelju odredaba Haaških regulacija kojima je normiran položaj neregularnih vojnih snaga, odnosno prema terminologiji međunarodnoga ratnog prava odnosio se na jedinice milicije i dobrovoljnih odreda (gerila) u ratnim okolnostima. ${ }^{62}$ Upravo su partizani tijekom Drugoga svjetskog rata bili ogledni primjer dobrovoljačkih odreda koji su primjenjivali nekonvencionalne, odnosno gerilske oblike ratovanja, a čije se djelovanje u početnim godinama rata svodilo na izvođenje manjih akcija, sabotaža i diverzija. Osim podnijetoga zahtjeva da se tretiraju kao ratni zarobljenici, MOCK je u spomenutom apelu zatražio i da se poštuju načela Ženevske konvencije o poboljšanju položaja ranjenih i bolesnih pripadnika oružanih snaga na bojnom polju. Istodobno je u Zagrebu stalni predstavnik Schmidlin, osobito od jeseni 1944., intervenirao kod Središnjega ureda HCK-a, ministarstava unutarnjih i vanjskih poslova NDH te predsjednika Hrvatske državne vlade Nikole Mandića zahtijevajući da se partizanima službeno prizna položaj zaraćene strane. ${ }^{63}$

Iako predstavnici partizanskoga pokreta de iure nisu ostvarili položaj zaraćene strane priznate od Njemačkoga Reicha, iz navedenoga je vidljivo da su takvi odnosi održavani de facto. Bila je to posljedica i stalne promjene stava u njemačkom vodstvu. Primjerice, Hitler je u ljeto 1944. iznova inzistirao da se u službenim dokumentima o jugoslavenskom ratištu za partizane koriste isključivo termini „komunisti” ili „komunističke bande”. ${ }^{4}$ No samo dva dana nakon apela MOCK-a da se zarobljeni partizani tretiraju prema propisima međunarodnoga ratnog prava, na upit upućen Vrhovnom zapovjedništvu oružanih snaga Reicha (Oberkommando der Wehrmacht - OKW) o mogućnostima posjeta jugoslavenskim partizanima OKW je odgovorio da se „partizani s balkanskih prostora na području Reicha tretiraju kao ratni zarobljenici i mogu primati pomoć i posjete predstavnika MOCK-a” ${ }^{65} \mathrm{U}$ toj odluci međutim nigdje nisu spomenute Ženevske konvencije, a već 2. rujna 1944. na zahtjev MOCK-a da se njegovim predstavnicima odobre posjeti logorima u kojima su zatočeni jugoslavenski partizani OKW je odgovorio negativno uz obrazloženje da je odluka izdana krajem kolovoza 1944. „pogrešno protumačena" ${ }^{66} \mathrm{O}$ složenoj situaciji i suprotstavljenim gledištima njemačkih vojnih

61 Isto.

$62 \$ 1 ., \$ 2 ., \$ 3 . \mathrm{u}:$ BROWN SCOTT, The Hague Conventions and Declarations of 1899 and 1907, 107-108.

63 CH-ACICR, G. 17/00/139, G. 17/00-6.2 = G. 17/00 III, Mémorandum au Gouvernement yougoslave, 4. 3. 1947., 39-40.

64 KISIĆ KOLANOVIĆ, NDH i Italija, 303.

65 CH-ACICR, G. 17/00-I., Généralités PG, 1942-1945. Dopis br. 9.406 R. Martija, stalnoga predstavnika u Berlinu, upućen Tajništvu MOCK-a, 25. 8. 1944.

66 CH-ACICR, C G2 YU 52 = G2 YU 1994.0046.00093, Partisans, Dopis br. 9.500 R. Martija, stalnoga predstavnika MOCK-a u Berlinu, upućen Tajništvu MOCK-a, 2. 9. 1944.; 
zapovjednika na terenu, OKW-a, ali i stavu vojnih vlasti NDH u odnosu na partizane, zorno svjedoči i jedan dokument Ureda ministra Ministarstva unutarnjih poslova NDH od 9. listopada 1944. upućen Predsjedništvu Vlade te Ministarstvu vanjskih poslova NDH. U dokumentu se navodi da je Izvještajni odjel Ministarstva oružanih snaga dopisom od 29. kolovoza 1944. izvijestio o izdavanju zapovijedi da se „zarobljeni partizani (odmetnici)” predaju redarstvenim oblastima, što neće biti moguće provesti ako ih zarobe njemačke oružane snage budući da „njemačke vlasti partizanskim borcima priznaju prava ratnih zarobljenika, a kao takove zadržavaju ih pod vlastitim nadzorom". ${ }^{67}$ Stoga je Ministarstvo oružanih snaga izdalo okružnicu podređenim zapovjedništvima da se uhvaćeni „partizanski i drugi odmetnički borci [...], neće smatrati ratnim zarobljenicima", što vrijedi i za vojne i građanske osobe koje imaju strano državljanstvo, a budu uhvaćene da se bore na strani partizana. ${ }^{68}$ Iz samoga je dokumenta očito da je zapovjedništvo njemačkih snaga $\mathrm{u}$ NDH partizane tretiralo kao zaraćenu stranu i prema njima se odnosilo $\mathrm{u}$ skladu s odredbama Ženevskih konvencija, a vlasti NDH, iako je bilo i amnestija, iz političkih razloga i dalje su ih tretirale kao političke zatočenike i komunističke bandite.

\section{Uspostava službenih odnosa}

Nakon ostvarenih neslužbenih kontakata u ljeto 1943., krajem te godine i sredinom iduće javlja se nekoliko novih momenata u međusobnim odnosima koji su utjecali na pregovore o uspostavi službenih odnosa između MOCK-a i pripadnika partizanskoga pokreta. Naime, krajem 1943. ili početkom 1944. partizanska pomorska baza stacionirana je u Italiji pokraj Barija. ${ }^{69}$ Kako se u Bariju nalazilo Stalno predstavništvo MOCK-a, preko njega su, slanjem pomoći i rješavanjem problematike raseljenih osoba, održavani službeni kontakti s jugoslavenskim partizanima. Budući da je ratna situacija kočila uspostavu izravnih veza, pomoć MOCK-a i Lige društava Crvenoga križa jugoslavenskim je partizanima, odnosno stanovništvu na oslobođenim područjima dostavljana preko predstavništva MOCK-a iz Zagreba (Schmidlin) i Beograda (Vögeli), zatim, kako se bližio kraj rata, željezničkom trasom Budimpešta - Novi Sad - Beograd, a naposljetku su sve pošiljke pomoći odašiljane brodskom linijom Marseille - Bari, odakle je pomoć isporučivalo zrakoplovstvo (do Beograda). ${ }^{70}$

Pitanje uspostavljanja službenih odnosa na red je došlo sredinom 1944. godine. No da bi se taj proces realizirao, trebalo je zadovoljiti nekoliko temeljnih preduvjeta, odnosno MOCK je trebao provesti „verifikacijski postupak”

CH-ACICR, G. 17/00/139, G. 17/00-6.2 = G. 17/00 III, Mémorandum au Gouvernement yougoslave, 4. 3. 1947., 38.

67 MILETIĆ, Koncentracioni logor Jasenovac, knj. II, 787-788.

68 Isto.

69 KISIĆ KOLANOVIĆ, NDH i Italija, 405.

70 Report of the Joint Relief Commission, 350-351. 
na temelju sustavnoga postupka priznavanja novih nacionalnih društava koji se primjenjivao još od 1876 . godine. ${ }^{71}$ Za razliku od zahtjeva nacionalnih društava, koja su od MOCK-a tražila priznanje, u odnosima s jugoslavenskim partizanima bila je suprotna situacija jer je poticaj došao od vodstva MOCK-a, a ne jugoslavenske nacionalne organizacije Crvenoga križa. Prema temeljnim kriterijima jedinstva, neovisnosti i univerzalnosti jugoslavenski su partizani, osim osnutka organizacije Crvenoga križa s mrežom lokalnih ogranaka, trebali imati službeno izabrano vodstvo koje su potvrdile vlasti, djelovati kao jedina i jedinstvena nacionalna organizacija na terenu cijele države te izraziti spremnost da će sudjelovati u svim aktivnostima Međunarodnoga pokreta Crvenoga križa uvažavajući njegova temeljna načela rada. ${ }^{72} \mathrm{U}$ svjetlu tih preduvjeta postojale su otegotne okolnosti koje su utjecale na mogućnost uspostave službenih odnosa. Naime, pripadnici partizanskoga pokreta nisu se obratili MOCK-u za priznanje nacionalne organizacije Crvenoga križa, što je bio temeljni preduvjet uspostave službenih odnosa. Istodobno je postojala i djelovala izbjeglička nacionalna organizacija (Jugoslavenski odbor Crvenog krsta - JOCK), čiji je rad obnovljen u Londonu, gdje se smjestila i izbjeglička jugoslavenska kraljevska vlada, čije je interese gotovo cijelo vrijeme rata u Ženevi zastupao dr. Svetozar Moačanin, potpredsjednik JOCK-a, kojega je izbjeglička vlada 25. srpnja 1942. akreditirala za posebnoga predstavnika JOCK-a u povjerljivoj misiji pri MOCK-u u Ženevi. ${ }^{73}$ JOCK, odnosno njegov predstavnik $\mathrm{u}$ Ženevi imali su potpuni legitimitet u međunarodnopravnim okvirima jer je vodstvo MOCK-a - usprkos imenovanju i radu preko stalnoga predstavnika u Zagrebu (pri HCK-u i vlastima NDH) i agenta za vezu u Beogradu (kod tamošnje organizacije Crvenoga krsta i vlasti Milana Nedića, odnosno Srbije pod njemačkom vojnom upravom), a zatim i dodirima s pripadnicima partizanskoga pokreta - ostalo pri odluci objavljenoj u okružnici br. 365 od 17. rujna 1941. prema kojoj je priznavanje nacionalnih društava Crvenoga križa zbog ratnih okolnosti suspendirano do završetka rata. ${ }^{74} \mathrm{U}$ odgovoru Američkom Crvenom križu na upit o suradnji s novim organizacijama Crvenoga križa koje su utemeljene na okupiranim područjima Europe dr. Max Huber, predsjednik MOCK-a, referirao se na spomenutu okružnicu te sugerirao da se komunikacija s nepriznatim društvima odvija preko MOCK-a. ${ }^{75} \mathrm{U}$ situ-

${ }^{71}$ Detaljno o unificiranom postupku priznanja usp. KEVO, „Imenovanje stalnog predstavnika”, 213-217.

72 Isto, 215.

73 CH-ACICR, G. 85/Yougoslavie, Correspondance reçue (29. 11. 1939. - 31. 5. 1945.). Obavijest jugoslavenskoga kraljevskog poslanstva iz Berna upućena Tajništvu MOCK-a, 25. 7. 1942.

74 Integralni tekst okružnice u: „Constitution et situations particulières des Sociétés de Croix-Rouge en temps de guerre”, 763-767.

75 CH-ACICR, G. 21, Croix-Rouges sur territoires étrangères, 1939-1950., Pays O-Z (1939. - 1948.), fasc. 1 (Croix-Rouge sur territoires étrangers /A-B/, 25. 5. 1947. - 8. 7. 1949.), fasc. Généralités (31. 10. 1940. - 28. 6. 1948.), br. 1 - Upit predsjednika Središnjega ureda Američkoga Crvenoga križa od 22. 9. 1941. upućen dr. Maxu Huberu, br. 4, 1-2 - Odgovor predsjednika Središnjega ureda Američkoga Crvenoga križa od 20. 12. 1941. povodom Huberova povjerljivoga pisma od 18. 11. 1941. 
aciji kad je postojalo više nacionalnih organizacija Crvenoga križa, odnosno organizacija u izbjeglištvu te novoosnovana organizacija u okupiranoj državi, Američki Crveni križ odlučio se pridržavati drugoga prijedloga, kojim je dr. Huber sugerirao da se komunikacija s priznatim nacionalnim organizacijama Crvenoga križa u izbjeglištvu održava preko nacionalnoga društva države u koju se smjestilo izbjegličko društvo Crvenoga križa, ali istodobno je država trebala ugostiti i izbjegličku vladu okupirane države. ${ }^{76}$ Prema tome, jedino je JOCK (London) bio punopravni član Pokreta Crvenoga križa, imao legitimitet i bio međunarodno priznato društvo. Usprkos tome, a na osnovi načela izbjegavanja konfrontacija i kompromisnoga odnosa sa svim (ne)službenim zaraćenim stranama, vodstvo MOCK-a još je u ljeto 1943. stupilo u kontakt s predstavnicima partizanskoga pokreta da ne trpi rad u korist ratnih stradalnika.

Novi moment u međusobnim odnosima nastupio je u ljeto 1944. nakon potpisivanja sporazuma između Tita kao predsjednika Nacionalnoga komiteta oslobođenja Jugoslavije (NKOJ), odnosno Demokratske Federativne Jugoslavije (DFJ), te dr. Ivana Šubašića, predstavnika izbjegličke kraljevske vlade iz Londona, koji su prema Slobodanu Nešoviću otvorili put međunarodnom priznanju nove Jugoslavije. ${ }^{77}$ Budući da je u svojem radu vodstvo MOCK-a slijedilo švicarsku vanjskopolitičku orijentaciju, koja se pak oslanjala na smjer britanske vanjske politike, spomenuti su sporazumi olakšali realizaciju već uspostavljenih kontakata. Da su toga bili svjesni i u vodstvu partizanskoga pokreta potvrđuje i ubrzan razvoj mreže lokalnih ogranaka Crvenoga križa, što je bio jedan od temeljnih preduvjeta za uspostavu službenih odnosa. O takvoj namjeri zorno svjedoči jedan dokument Oblasnoga narodnooslobodilačkog odbora (ONOO) Varaždin od 27. rujna 1944., koji potvrđuje i postojanje lokalnih organizacija, a temeljio se na okružnici Društva Crvenog krsta DFJ razaslanoj po cijeloj Hrvatskoj. ${ }^{78}$ Naime, Crveni krst DFJ zatražio je od oblasnih, općinskih i kotarskih (sreskih) odbora Crvenoga križa dostavu podataka o stanju u zemlji (stanje prehrane; relativni udio smrtnosti od gladi; relativni udio TBC bolesnika; pojave epidemija; stanje endemskih bolesti; zdravstveno stanje djece) da bi se Jugoslavija za pomoć obratila „Međunarodnom Crvenom krstu”, Saveznicima i UNRRA-i. ${ }^{79}$ Potvrđuje to i dopis Stalnoga predstavništva MOCK-a koji je 29. rujna 1944. upućen Središnjici u Ženevu i Mješovitom povjerenstvu za pomoć, u kojem se navodi da su pod pokroviteljstvom NKOJ-a na oslobođenim područjima osnovani brojni lokalni ogranci Crvenoga križa. ${ }^{80}$ Ovdje treba dodati i da je nešto prije prvi kontakt

76 CH-ACICR, G. 21, Croix-Rouges sur territoires étrangères, 1939-1950., Pays O-Z (1939. 1948.), fasc. 1 (Croix-Rouge sur territoires étrangers /A-B/, 25. 5. 1947. - 8. 7. 1949.), fasc. Généralités (31. 10. 1940. - 28. 6. 1948.), br. 4, 1 - Odgovor predsjednika Središnjega ureda Američkoga Crvenoga križa od 20. 12. 1941. povodom Huberova povjerljivoga pisma od 18. 11. 1941.

77 NEŠOVIĆ, Diplomatska igra oko Jugoslavije, 58. Ukratko o pregovorima: JAKOVINA, Američki komunistički saveznik, $20 \mathrm{i}$ d.

78 HR-DAVŽ-0019-ONOO Varaždin (1943. - 1945.), Tajništvo: Opći spisi, 225/44. (kut. 3).

79 Isto.

80 CH-ACICR, G. 21, Croix-Rouges sur territoires étrangères, 1939-1950., Pays O-Z (1939. 
ostvarila slovenska sekcija novoga društva, koja se 11. rujna 1944. obratila Središnjici MOCK-a šaljući obavijest o osnivanju podružnice „novog Jugoslavenskog Crvenog križa” na područjima koja su oslobodili pripadnici Narodnooslobodilačke vojske Jugoslavije, zatim je navela da se u radu pridržava statuta MOCK-a te da nema nikakve veze sa slovenskom organizacijom Crvenoga križa iz Ljubljane koja djeluje na teritoriju koji su okupirali Nijemci. ${ }^{81}$ Paralelno s ustrojavanjem organizacije Crvenoga križa na područjima pod kontrolom pripadnika NOV i POJ ostvareni su i službeni kontakti s predstavnicima MOCK-a. Međutim, prije toga dogodio se ozbiljan zaokret u politici vodstva MOCK-a prema zahtjevima izbjegličke kraljevske vlade iz Londona, što se odrazilo na zahtjev od 27. srpnja 1944. da se dr. Moačanin, dotadašnji posebni predstavnik pred organizacijama Crvenoga križa u Ženevi, podigne na položaj akreditiranoga stalnog predstavnika pri MOCK-u „sa svim povlasticama koje mu pripadaju kao i drugim službenim predstavnicima nacionalnih društava Crvenog križa akreditiranima u Ženevi”. ${ }^{82}$ Obrazlažući praksu nepriznavanja novih društava nastalih u ratnim okolnostima, dr. Huber je 17. kolovoza 1944. obavijestio jugoslavensko kraljevsko poslanstvo u Bernu da ne može izdati službeni agreman i prihvatiti zahtjev da se dr. Moačanina podigne na položaj akreditiranoga stalnog predstavnika. ${ }^{83}$ Iznimno je to zanimljivo budući da je u prethodnom razdoblju, osobito u korespondenciji sa Središnjim uredom Američkoga Crvenog križa, tvrdio da se izbjegličke organizacije Crvenoga križa mogu smatrati legitimnima ako je država u kojoj djeluju ugostila i izbjegličku vladu okupirane države, a upravo je takav bio ovaj slučaj jer su i JOCK i izbjeglička vlada sjedište imali u Londonu.

Krajem rujna i početkom listopada 1944. Stalnom predstavništvu MOCK-a u Londonu s više dopisa obratili su se predstavnici kraljevske vlade dr. Šubašića te NKOJ-a i maršala Tita, odnosno DFJ ustrojene odlukama 2. zasjedanja AVNOJ-a, da bi ih upoznali s promjenama u organizaciji nacionalne organizacije Crvenoga križa Jugoslavije. Tako je Stalno predstavništvo MOCK-a u Londonu zaprimilo dopis jugoslavenskih vlasti o osnivanju Središnjega odbora Jugoslavenskoga Crvenoga križa (JCK) kao središnjega upravnog tijela nacionalne organizacije koju su priznale središnje državne vlasti, ali i upit Američkoga Crvenoga križa o postupanju prema novoj organizaciji jer su diplomatskim putem zaprimili obavijest da je reorganizacija nacionalne organizacije na oslobođenom području dovršena, dok su članovi

- 1948.), fasc. 2 (Croix-Rouge sur territoires étrangers /C-G/, 21. 6. 1938. - 17. 9. 1948.), Dopis Stalnoga predstavništva MOCK-a iz Londona od 29. 9. 1944.

81 Croix-Rouge Slovène, Section de la novelle Croix-Rouge Yougoslave, CH-ACICR, CR 00/52-196, Croix-Rouge yougoslave (201-397, 20. 3. 1934. - 6. 11. 1950.), 256bis.

82 CH-ACICR, G. 85/Yougoslavie, Correspondance reçue (29. 11. 1939. - 31. 5. 1945.). Dopis jugoslavenskoga kraljevskog poslanstva iz Berna upućen dr. Maxu Huberu, predsjedniku MOCK-a, 27. 7. 1944.

83 CH-ACICR, G. 85/Yougoslavie, Correspondance envoyée (25. 9. 1942. - 29. 4. 1950.), fasc. 1.2 (25. 9. 1942. - 29. 12. 1944.). Pismo dr. Hubera od 17. 8. 1944. upućeno jugoslavenskom kraljevskom poslanstvu u Bernu. 
jugoslavenske kraljevske obitelji podnijeli ostavke u predsjedništvu JOCK-a u Londonu. ${ }^{84} \mathrm{U}$ pismima od 7. listopada 1944. koje je Stalnom poslanstvu MOCK-a u Londonu uputio ministar unutrašnjih poslova Sava Kosanović naglašeno je da je novi Središnji odbor JCK-a, osnovan na otoku Visu, za čijega je predsjednika izabran dr. Vojislav Kecmanović, jedina legitimna organizacija Crvenoga križa u Jugoslaviji koju priznaju vlasti te MOCK treba obustaviti održavanje bilo kakvih kontakata s organizacijama Crvenoga križa koje su u ratnim okolnostima osnovane na okupiranim područjima i imale su sjedište u Ljubljani, Zagrebu, Beogradu i Cetinju. ${ }^{85}$ Bila je to posljedica odluke Ministarskoga savjeta od 6. listopada 1944. kojom je raspušten izbjeglički JOCK, čime je dovršeno ujedinjavanje središnjih tijela JCK-a iz zemlje i izbjeglištva. ${ }^{86}$ Istovjetne podatke donosi i jugoslavenski diplomat Vladimir Velebit, koji je u to doba bio šef Vojne misije Vrhovnoga štaba Narodnooslobodilačke vojske Jugoslavije u Velikoj Britaniji (London), uz napomenu da je izbjeglički JOCK bio neprijateljski nastrojen prema partizanima te da nije želio preko međunarodne organizacije kojoj je pripadao obavljati rad na oslobođenim područjima Jugoslavije, pa se nakon sporazuma s kraljevskom vladom otvorila mogućnost da se „likvidira”. ${ }^{87}$

Osim organizacije lokalnih ogranaka, jugoslavenske su vlasti zadovoljile i druga načela tvrdeći da se radi o jedinstvenoj nacionalnoj organizaciji Crvenoga križa koja je imala središnju upravu potvrđenu od središnjih vlasti i predstavljala je jedinu organizaciju Crvenoga križa na području države. Istodobno su jugoslavenski predstavnici zatražili da se korespondencija obavlja isključivo preko ovlaštenih predstavnika JCK-a u Londonu dr. Kriste Đorđević i dr. Nikole Nikolića, predsjednika Zdravstvenoga odsjeka jugoslavenske Vojne misije maršala Tita u Londonu, koji je ubrzo osobno preuzeo nadležnost nad cjelokupnom korespondencijom sa službama MOCK-a. ${ }^{88}$

Premda je MOCK još od kolovoza 1943. održavao kontakte s pripadnicima partizanskoga pokreta, službeno su odnosi uspostavljeni tek krajem 1944., a realizacija dugotrajnoga procesa nije značila skretanje s puta proklamirane neutralnosti. Iako bi se moglo zaključiti da je uspostava službenih veza bila

${ }^{84}$ CH-ACICR, CR 00/52-196, Croix-Rouge yougoslave (201-397, 20. 3. 1934. - 6. 11. 1950.), 259 - Dopis Stalnoga predstavništva MOCK-a iz Londona od 29. 9. 1944. upućen Središnjoj agenciji za ratne zarobljenike MOCK-a; 264, 268 - Radiogrami iz Washingtona, 21. i 23. 10. 1944.

85 CH-ACICR, CR 00/52-196, Croix-Rouge yougoslave (201-397, 20. 3. 1934. - 6. 11. 1950.), 266 - Dopis br. 4828 Stalnoga predstavništva MOCK-a iz Londona od 11. 10. 1944. upućen Središnjici MOCK-a u Ženevu.

86 CH-ACICR, CR 00/52-196, Croix-Rouge yougoslave (201-397, 20. 3. 1934. - 6. 11. 1950.), 269 - Prijepis dekreta jugoslavenskoga Ministarskog savjeta od 6. listopada 1944. o odlukama u vezi s JCK-om izvan državnih granica (datiran 17. listopada), Prilog uz dopis br. 4907 Stalnoga predstavništva MOCK-a iz Londona od 25. 10. 1944. upućen MOCK-u u Ženevu, 2-4.

87 VELEBIT, Sjećanja, 314-315.

88 CH-ACICR, CR 00/52-196, Croix-Rouge yougoslave (201-397, 20. 3. 1934. - 6. 11. 1950.), 259 - Dopis Stalnoga predstavništva MOCK-a iz Londona od 29. 9. 1944. upućen Središnjoj agenciji za ratne zarobljenike MOCK-a. 
kršenje načela neutralnosti, odnosno nepriznavanja organizacija nastalih u ratnim okolnostima, to ipak nije bio slučaj. S pravnoga gledišta, jasno je da su u prethodnom razdoblju postojale izvjesne dvojbe o uspostavljanju suradnje, ali su uklonjene nakon sporazuma Tito-Šubašić. O tome svjedoči i odgovor MOCK-a na upite koje je o suradnji s predstavnicima izbjegličkih odbora Crvenoga križa više zemalja, ali i s predstavnicima njihovih nacionalnih organizacija u zemlji, zatražio Američki Crveni križ. U odgovoru MOCK-a od 25. rujna 1945. rečeno je da je priznavanje novih nacionalnih društava u ratu bilo suspendirano, ali priznanje JCK-a (osnovan 1944.) nije bilo iznimka jer se radilo o nacionalnoj organizaciji koja je bila pravni sljednik JOCK-a, koji je od 1941. djelovao u izbjeglištvu, priznatog od Međunarodnoga odbora. Odgovor je MOCK poslao svojim stalnim predstavništvima u Trstu, Milanu, Rimu i Beogradu jer se doticao problematike priznanja i Talijanskoga i Jugoslavenskoga Crvenoga križa, nastalih krajem rata, čiji su lokalni ogranci, doduše neslužbeno, djelovali u Trstu i Puli, a koje je MOCK smatrao disidentskima, odbio ih je priznati i sugerirao je da se na tom području komunicira isključivo s predstavnicima Američkoga ili Britanskoga Crvenoga križa. ${ }^{89}$

U ulozi akreditiranoga diplomatskog predstavnika pred organizacijama Crvenoga križa (MOCK, MCK) u Ženevi dr. Nikolić se pojavio početkom prosinca 1944., odnosno kad je 5. prosinca posjetio Središnjicu MOCK-a, gdje su ga primili novoizabrani predsjednik MOCK-a dr. Jakob Carl Burckhardt i član Tajništva MOCK-a zadužen za zarobljeničku problematiku Roger Gallopin. ${ }^{90}$ Razgovaralo se o više pitanja, a dr. Nikolić je obavijestio vodstvo MOCK-a da se dr. Moačanin više ne smatra službenim predstavnikom JCK-a u Ženevi, pa do imenovanja novoga stalnog predstavnika korespondenciju treba obavljati preko dr. Mladena Mažuranića Jankovića, atašea pri Stalnom predstavništvu JCK-a, koji je bio u njegovoj pratnji i prisustvovao sastanku. ${ }^{91}$ Prema navodima iz izvješća dr. Hansa Wolfa de Salisa, stalnoga predstavnika MOCK-a u Rimu, jugoslavenske su vlasti samo nekoliko dana prije toga

89 CH-ACICR, G. 21, Croix-Rouges sur territoires étrangères, 1939-1950., Pays O-Z (1939. - 1948). fasc. 1 (Croix-Rouge sur territoires étrangers /A-B/, 25. 5. 1947. - 8. 7. 1949.), fasc. Généralités (31. 10. 1940. - 28. 6. 1948.), Dopis MOCK-a upućen stalnim predstavništvima u Trstu, Milanu, Rimu i Beogradu, 25. 9. 1945.

90 CH-ACICR, APCICR, Gallopin, Roger. Roger Gallopin, član Središnjega (od 1944. Općega) tajništva MOCK-a nadležan za Odjel za problematiku ratnih zarobljenika, interniranih civila i civila (Division des Prisonniers, des Internés civils et des Civils du CICR), zatim Središnju agenciju za ratne zarobljenike MOCK-a te Odjel stalnih predstavništava, poslanstava i izaslanstava MOCK-a (Division des délégations du CICR). Od 1942. član je Povjerenstva za civile i internirane civile (Commission des Prisonniers, des Internés civils et des Civils) nadležnog za problematiku političkih zatvorenika, žrtava rasnih progona te civila u zaštitnoj internaciji. Od proljeća 1944. član je i Upravnoga odbora nadležnog Odjelu za posebnu pomoć (Division d'assistance spéciale) MOCK-a, zaduženog za skupnu i pojedinačnu pomoć u korist civila u zaraćenim i okupiranim državama (deportirane osobe, politički zatvorenici, administrativni zatočenici, žrtve rasnih progona) koji nisu uživali zaštitu normiranoga međunarodnoga ratnog prava.

91 CH-ACICR, CR 00/52-196, Croix-Rouge yougoslave (201-397, 20. 3. 1934. - 6. 11. 1950.), 279 - Zapisnik sa sastanka, 5. 12. 1944., 1. 
sastanka stalnim predstavnikom JCK-a u Ženevi imenovale dr. Mikolu (Nikolu) Miceva, a interese organizacije zastupali su i akreditirani opunomoćeni predstavnici pukovnik dr. Borislav Božović u Bariju, kapetan Krajger kao pomoćni predstavnik u Rimu, gdje je zamijenio Slavena Smodlaku, te dr. Nikolić u Londonu..$^{92}$ Posljednja točka razgovora ticala se problematike humanitarne pomoći za Jugoslaviju, a jugoslavenski predstavnici zatražili su da se nastavi sa slanjem pomoći, osobito za djecu kojoj je bila potrebna medicinska pomoć. ${ }^{93}$ Glede pitanja humanitarne pomoći dr. Burckhardt i Gallopin obećali su se obratiti Američkom Crvenom križu, ali su savjetovali da se jugoslavenski predstavnici za pomoć obrate nacionalnim društvima Crvenoga križa, prije svega švicarskom, ali isto tako neka stupe u kontakt s nacionalnim organizacijama Crvenoga križa savezničkih zemalja. Vodstvo MOCK-a udovoljilo je zahtjevu u svezi s imenovanjem dodatnoga predstavnika u Beogradu, što je očito iz jedne obavijesti od 25. siječnja 1945. u kojoj se navodi da dužnost voditelja Stalnoga predstavništva u Beogradu obavlja dr. Rudolf Vögeli, kome je za pomoćnoga predstavnika (Délégué-adjoint) dodijeljen Rudolf (Rodolphe) Schindler, koji je u Beograd stigao tek krajem travnja 1945. godine. ${ }^{94}$

Vezano uz kadrovske promjene treba dodati da je u studenome 1944. odstupio dr. Moačanin, posebni predstavnik izbjegličkoga kraljevskog JOCK-a pri organizacijama Crvenoga križa u Ženevi. ${ }^{95}$ Iako u dopisu Stalnoga predstavništva MOCK-a iz Londona krajem rujna nije poimenično naveden, čini se da je ostavka dr. Moačanina bila osobna odluka jer se u tom dopisu kaže da je potpredsjednik JOCK-a ponudio ostavku da bi došlo do „unifikacije”, odnosno ujedinjavanja jugoslavenskih organizacija u zemlji i izbjeglištvu u jedinstveno nacionalno društvo Crvenoga križa. ${ }^{96}$ Do dolaska novoimenovanoga stalnog predstavnika u Ženevu korespondenciju je na sebe preuzeo dr. Milislav Obradović, pomoćni predstavnik Stalnoga predstavništva JCK-a u Ženevi. ${ }^{97} \mathrm{U}$ jeku kadrovskih promjena koje su obilježile prvih nekoliko mjeseci nakon uspostave službenih odnosa cjelokupnu aktivnost između JCK-a i

92 CH-ACICR, CR 00/52-196, Croix-Rouge yougoslave (201-397, 20. 3. 1934. - 6. 11. 1950.), 277 - De Salisovo izvješće upućeno Središnjici MOCK-a, 26. 11. 1944., 1, 2, 7, 8. Nisam uspio utvrditi osobno ime kapetana Krajgera, ali može se raditi o Borisu Kraigheru.

93 CH-ACICR, CR 00/52-196, Croix-Rouge yougoslave (201-397, 20. 3. 1934. - 6. 11. 1950.), 279 - Visite du Colonel Nikolić, 5. 12. 1944., 2.

94 CH-ACICR, CR 00/52-196, Croix-Rouge yougoslave (201-397, 20. 3. 1934. - 6. 11. 1950.), 283 - Brzojav Stalnom predstavništvu u Rimu, 25. 1. 1945.; CH-ACICR, G. 85/Yougoslavie, Correspondance envoyée (24. 11. 1943. - 15. 6. 1945.), Dopis R. Frick-Cramer od 24. 4. 1945.

95 CH-ACICR, G. 85/Yougoslavie, fasc. Correspondance envoyée (24. 11. 1943. - 15. 6. 1945.), Dopis J. Picteta od 20. 12. 1944.

96 CH-ACICR, G. 21, Croix-Rouges sur territoires étrangères, 1939-1950., Pays O-Z (1939. - 1948.), fasc. 2 (Croix-Rouge sur territoires étrangers /C-G/, 21. 6. 1938. - 17. 9. 1948.), Dopis Stalnoga predstavništva MOCK-a iz Londona, 29. 9. 1944.

97 CH-ACICR, G. 85/Yougoslavie, Correspondance reçue (29. 11. 1939. - 31. 5. 1945.), Obavijest jugoslavenskoga (kraljevskog) poslanstva iz Berna upućena MOCK-u, 18. 12. 1944.; G. 85/Yougoslavie, fasc. 1.1. Correspondance envoyée (24. 11. 1943. - 15. 6. 1945.), Dopis J. Picteta od 26. 12. 1944. 
MOCK-a održavao je dr. Nikolić, a ta je praksa nastavljena do svibnja 1945. kad su ga jugoslavenske vlasti imenovale stalnim predstavnikom JCK-a pri MOCK-u, a za pomoćnika mu je dodijeljen dr. Obradović. ${ }^{98}$

\section{Kršenja normi i običaja ratovanja}

Nakon uspostave službenih odnosa predstavnici MOCK-a započeli su na područjima pod kontrolom Narodnooslobodilačkoga pokreta Jugoslavije opsežnu aktivnost u korist ratnih stradalnika. Iako su dotad najviše surađivali s nacionalnom organizacijom Crvenoga križa NDH, čija se djelatnost, kako se bližio kraj rata, polako gasila, sve su više bili usmjereni na veze s predstavnicima partizanskoga pokreta. Budući da su prometne veze u NDH između Zagreba i ostalih dijelova države bile ograničene, prekinute ili se putovalo na vlastitu odgovornost, aktivnost MOCK-a na području NDH imala je ograničeni karakter i opseg je ovisio o osobnom angažmanu stalnoga predstavnika Schmidlina, čiji je rad bio ograničen na Zagreb jer su mu drugi dijelovi zemlje bili nedostupni. ${ }^{99} \mathrm{Na}$ tim nedostupnim područjima MOCK je djelovao preko dr. Vögelija, dotadašnjega agenta za vezu MOCK-a koji je djelovao u Srbiji pod njemačkom vojnom upravom, a nakon što su krajem listopada 1944. jedinice NOV i POJ uz pomoć snaga Crvene armije zauzele Beograd, koji je postao sjedište središnjih vlasti nove Jugoslavije, dr. Vögeli je postao ovlašteni predstavnik MOCK-a i radio je u dogovoru s predstavnicima maršala Tita i sa Saveznicima. Jedan od glavnih aspekata opsežne aktivnosti MOCK-a u korist potrebitih bilo je otpremanje pomoći kategorizirane na osnovi četiriju kategorija korisnika za vrijeme rata. ${ }^{100}$ Usprkos ograničenjima, stalni predstavnik Schmidlin uspješno je prikupljao podatke i izvještavao Središnjicu u Ženevi o složenoj humanitarnoj situaciji na području NDH, osobito o veoma teškim prilikama na područjima nad kojima su kontrolu preuzele jedinice NOV i POJ. Na oslobođenim se područjima od kraja 1943. osjećao nedostatak hrane, a nakon kapitulacije Kraljevine Italije znatno je porastao broj izbjeglih i raseljenih osoba koje su partizani prebacivali na srednjodalmatinske otoke. Uz pristanak Savezničkoga vojnog zapovjedništva na Sredozemlju, raseljene osobe prebačene su krajem 1943. i početkom 1944. u južnu Italiju te u Egipat, gdje je jugoslavenski zbjeg činilo oko 35 tisuća osoba, a transporte su pomagala stalna predstavništva MOCK-a iz Barija i Napulja, iako se to u radovima Mate

98 CH-ACICR, C G2 YU 51 = G2 YU 1994.046.0092, Légation et Consulats Yougoslavie, Tracing Bureau. Dopis kraljevskoga poslanstva iz Berna, 31. 5. 1945.

99 KEVO, Veze Međunarodnog odbora Crvenog križa i Nezavisne Države Hrvatske, sv. I., 168-169.

100 Prva kategorija bile su pošiljke pomoći za ratne zarobljenike i internirane civile; zatim pošiljke za deportirane civile i političke zatvorenike; pomoć za civilno stanovništvo ugroženo ratnim okolnostima (djeca, žene, bolesnici, invalidi) te pomoć talijanskim i njemačkim zarobljenicima i civilima nakon završetka rata. Rapport du Comité International de la CroixRouge, vol. III, 7-8. 
Barbića i Dušana Plenče ne navodi. ${ }^{101}$ No, da bi se pomoglo civilnom stanovništvu na tim područjima, pokrenut je niz humanitarnih akcija posredstvom Mješovitoga povjerenstva za pomoć MOCK-a i Lige društava Crvenoga križa. ${ }^{102}$ Zbog manjka financijskih sredstava, ali više kao posljedica nemogućnosti nabave potrebne robe $\mathrm{u}$ Europi, MOCK se obratio predstavnicima maršala Tita i u suradnji sa svojim stalnim predstavništvima u Zagrebu, Alžiru, Kairu i Bukureštu osigurao je izvjesne količine pomoći, a zagrebački ured MOCK-a Schmidlinovim je posredovanjem na to područje dostavio izvjesne količine lijekova. ${ }^{103}$

Međunarodni odbor nastavio je krajem 1944. s aktivnostima u korist stanovništva na oslobođenim područjima Jugoslavije, a s predstavnicima maršala Tita dogovoreno je da dotadašnji ured MOCK-a u kojem je kao agent za vezu za vrijeme njemačke okupacije djelovao dr. Vögeli preraste u stalno predstavništvo MOCK-a u Jugoslaviji sa sjedištem u Beogradu, koje će djelovati do završetka rata, odnosno zaključenja neprijateljstava. ${ }^{104}$ Pošiljke pomoći pripremane su na temelju zahtjeva, u kojima su predstavnici jugoslavenskih vlasti osobito inzistirali na slanju liječnika, lijekova, živežnih namirnica i odjevnih predmeta. ${ }^{105}$ Stoga su sve veće količine medicinskih i farmaceutskih proizvoda, lijekova, živežnih namirnica i odjevnih predmeta preko Barija otpremane na oslobođena područja, ali rad u korist civila više nije dogovaran preko Zagreba (Schmidlin) ili Barija, što je bila dotadašnja uobičajena praksa, nego izravno preko Stalnoga predstavništva MOCK-a u Beogradu ili u kontaktima s ovlaštenim jugoslavenskim predstavnicima u Rimu i Ženevi. Istodobno su

${ }_{101}$ CH-ACICR, G. 17/00/139; Fasc. G. 1700-6.2 = G. 17/00 III, Généralité, Mémorandum au Gouvernement Yougoslave, 4. 3. 1947., 11. Usp. BARBIĆ, „Jugoslavenski zbjeg u južnoj Italiji i Egiptu”; PLENČA, Organizacija i evakuacija dalmatinskog zbjega. Vidi i: BRATANIĆ, „Hrvatski zbjegovi u Italiji od 1943. do 1945. godine".

102 Mješovito povjerenstvo za pomoć izvornoga naziva Commission Mixte de Secours de la Croix-Rouge Internationale (CMS), koje je u izvorima nazivano i Vereinigte Hilfswerk, Joint Relief Commission ili Joint Aid Commission, utemeljili su sredinom 1941. MOCK i Liga društava Crvenoga križa kao tijelo zaduženo za otpremanje pomoći u koncentracijske logore za ratne zarobljenike, internirane civile i Židove. Djelatnost Povjerenstva temeljila se na Statutu donesenom 23. srpnja 1941., a upravu je imalo posebno vijeće sastavljeno od predstavnika MOCK-a i Lige društava Crvenoga križa te vanjskih članova oko čijega su imenovanja bile suglasne obje organizacije. Na čelu CMS-a bio je izvršni voditelj dr. Robert Böhringer, visokopozicionirani član MOCK-a. Uslijed opsežnosti poslova CMS je razdvojen na manje ustrojbene jedinice, od kojih su najvažnije bile Farmaceutska služba (Service Pharmaceutique) te Služba za živežne namirnice i odjevne predmete (Service Vivres et Vêtements). Od važnijih problema koji su utjecali na rad Povjerenstva treba izdvojiti manjak financijskih sredstava, otežan prijevoz pomoći osobama u potrebi te ozbiljne probleme pri nabavljanju hrane, odjeće i lijekova, odnosno robe koja je često znala biti označena kao ratni materijal, pa su česti bili i problemi uzrokovani savezničkom blokadom i njemačkom kontrablokadom. CH-ACICR, G. 12, Méthodes et Plans du Travail du CICR, 1941. - 1950., G. 12/II - Organisation, Izvješće o ustrojstvu raznih službi MOCK-a, bez nadnevka, 2-3. Usp. Report of the Joint Relief Commission, 10-11, 144-145, 206.

${ }^{103}$ Rapport du Comité International de la Croix-Rouge, vol. III, 551.

104 Isto, 550.

105 CH-ACICR, CR 00/52-196, br. 277 - Izvješće dr. de Salisa, 28. 11. 1944., 1. 
uspostavljeni službeni kontakti s Jugoslavenskom službom Središnje agencije za ratne zarobljenike MOCK-a, koja je nakon uspostave poštanskoga prometa s Beogradom od 23. studenog 1944. održavala stalne veze s jugoslavenskim predstavnicima. ${ }^{106}$ Preko posrednika iz Rima Jugoslavenska služba primila je u prosincu 1944. i siječnju 1945. više od 20 tisuća poruka za jugoslavenske ratne zarobljenike koji su se nalazili u logorima na području Njemačkoga Reicha. ${ }^{107}$ Iznimno dobru suradnju predstavnika MOCK-a i jugoslavenskih partizana potvrđuju i crtice o radu Jugoslavenske službe Središnje agencije za ratne zarobljenike koje su objavljivane u službenoj reviji Međunarodnoga Crvenoga križa. Primjerice, u izdanju za travanj 1945. stoji da je ured JCK-a iz Rima uvelike pomogao radu Jugoslavenske službe jer mu je na raspolaganje stavio kurira, čime je ubrzana korespondencija s nekim prometno izoliranim područjima, što se osobito odnosilo na Dalmaciju, u koju su dotad obavijesti slane preko Beograda. ${ }^{108}$ Rad MOCK-a u korist jugoslavenskih državljana nešto prije službeno je potvrdila i Jaroslava Ribnikar, tajnica JCK-a, koja je krajem listopada 1944. dr. Hansu Wolfu de Salisu, stalnom predstavniku MOCK-a u Rimu, uputila pismo zahvale za aktivnosti i napore koje je u korist jugoslavenskih državljana u Italiji učinilo rimsko Stalno predstavništvo MOCK-a. ${ }^{109}$

Krajem 1944. u Ženevi su alarmirani zbog izbijanja epidemije tifusa na oslobođenim jugoslavenskim područjima, pa je Mješovito povjerenstvo za pomoć otpremilo više pošiljaka cjepiva, a Međunarodni odbor iz Ženeve zamolio je prof. Hermanna Moosera, predstojnika Higijenskoga instituta Sveučilišta u Zürichu, da preuzme vođenje posebne zdravstveno-medicinske misije na oslobođena područja kako bi na licu mjesta potvrdio vijest o izbijanju epidemije tifusa te poduzeo odgovarajuće korake za njezino suzbijanje. ${ }^{10}$

Osim spomenutih aktivnosti, najvažnija problematika iz djelokruga rada predstavnika MOCK-a na terenu pred kraj rata te u neposrednom poraću

106 Poslovi Jugoslavenske službe Središnje agencije za ratne zarobljenike svodili su se na potragu za zarobljenim i nestalim pripadnicima oružanih snaga, na potragu za civilima te spajanje raseljenih obitelji. Kartični indeks Jugoslavenske službe, koji je obuhvaćao sve jugoslavenske državljane, početkom 1944. sadržavao je oko 555 tisuća poimeničnih vojnih i civilnih uložaka iako nisu svi bili pripadnici partizanskoga pokreta. CH-ACICR, C G2 YU $39=$ G2 YU 1994.0046.00055, Organisation du Service, Rapports d'activité, Statistiques, Modèles de fiches. Izvješće o Jugoslavenskoj službi, 11. 2. 1944., 7-8; Revue Internationale de la CroixRouge, XXVI, No. 303, Mars 1944, 247-248; Revue Internationale de la Croix-Rouge, XXVII, No. 314, Février 1945, 138.

107 Revue Internationale de la Croix-Rouge, XXVII, No. 314, Février 1945, 138.

108 Revue Internationale de la Croix-Rouge, XXVII, No. 316, Avril 1945, 301.

109 CH-ACICR, CR 00/52-196, Croix-Rouge yougoslave (201-397, 20. 3. 1934. - 6. 11. 1950.), br. 277 - Izvješće dr. de Salisa, 28. 11. 1944., 1. Pismo zahvale od 25. 10. 1944. nalazi se u prilogu izvješća.

${ }_{110}$ CH-ACICR, G. 3/66, Yougoslavie (Mooser, décembre 1944. - avril 1945.), Dopis H. Bachmanna za Lombarda, predsjednika Povjerenstva predstavništava MOCK-a od 30. 11. 1944.; Report of the Joint Relief Commission, 348; Rapport du Comité International de la CroixRouge, vol. III, 550. 
bila je praktična primjena Ženevskih i Haaških konvencija. Naime, uloženi su iznimni napori da se jugoslavenske vlasti prema zarobljenicima odnose u skladu s načelima međunarodnoga ratnog prava, a takva obećanja savezničkim snagama dao je i maršal Tito. ${ }^{111} \mathrm{O}$ tome, među inim, svjedoči i depeša koju je 6. prosinca 1944. uputio 2. udarnom korpusu Narodnooslobodilačke vojske Jugoslavije, u kojoj je potvrdio da je Saveznicima zajamčio da će se prema zarobljenicima postupati „prema međunarodnim zakonima”.112 Takav stav potvrdilo je Ministarstvo socijalne politike DFJ, koje je tek 13. travnja 1945. odgovorilo na upite predstavnika MOCK-a od 10. i 12. siječnja 1945. o pridržavanju odredaba Ženevske konvencije, uz napomenu da će se odredbe primijeniti ako se dokaže da se na istovjetan način postupalo sa zarobljenim pripadnicima Jugoslavenske armije, zarobljenim pripadnicima jugoslavenske kraljevske vojske (1941.), kao i s „onima koji su bili zarobljeni kao partizani, vojnici narodno oslobodilačke vojske". ${ }^{113}$ Iluzorno je bilo očekivati da se ti zahtjevi mogu dokazati, a situacija na terenu to je potvrdila. Naime, slučajevi osvete nad ratnim zarobljenicima nisu bili strani u postupanju jedinica NOV i POJ, a u odgovoru britanskom premijeru Winstonu Churchillu još sredinom 1944. Tito je naglasio da je osvetoljubivost potaknuta njemačkim nepoštovanjem propisa u odnosu na partizanske zarobljenike. ${ }^{114}$ Usporedno s oslobađanjem dijelova Hrvatske jedinice NOV i POJ otvarale su od sredine 1944. u Slavoniji zarobljeničke logore i logore za prisilni rad, odnosno kažnjeničke logore i logore za internaciju, pa je samo na području Hrvatske do 30. travnja 1945. otvoreno 19 logora u kojima se nalazilo oko 80 tisuća zarobljenika. ${ }^{115}$

Posebno je pitanje bio odnos prema poraženom neprijatelju, a završnim vojnim operacijama Zagrebu su se približavale postrojbe Jugoslavenske armije. ${ }^{116}$ Stoga su vlasti NDH početkom svibnja 1945. započele povlačenje vojnih snaga, praćenih mnoštvom civila, prema savezničkim vojnim snagama u Austriji. Vlasti NDH tražile su za pripadnike vojnih postrojbi i civile primjenu odredaba međunarodnoga ratnog prava, odnosno načela Ženevskih

111 Ujesen 1944. Tito je odbacio svaku aluziju na mogućnost da će jedinice NOV-a nekorektno postupati sa zarobljenicima, a u više navrata izdao je zapovijedi da se s njima postupa u skladu s međunarodnim propisima. Prema: VODUŠEK STARIČ, Kako su komunisti osvojili vlast, 244. O problematici usp. i: BLUMENWITZ, Okupacija in revolucija v Sloveniji.

112 SPEHNJAK, Britanski pogled na Hrvatsku, 188.

113 CH-ACICR, G. D EUR YOUG 1, Dopis br. 1346 Ministarstva socijalne politike od 13. 4. 1945.

114 VODUŠEK STARIČ, Kako su komunisti osvojili vlast, 244.

115 DIZDAR et al., Partizanska $i$ komunistička represija i zločini u Hrvatskoj. Dokumenti, 43-44, 53-55; GEIGER, Partizanska i komunistička represija i zločini u Hrvatskoj, sv. 2, 51, 54-55, 69-70, 102-104, 135-137; GEIGER et al., Partizanska i komunistička represija i zločini u Hrvatskoj, sv. 3, 74-75. O odmazdi vidi: GEIGER, LEČEK, „Politika retribucije u Europi nakon Drugoga svjetskog rata", 7-34. O odnosu prema ratnim zarobljenicima vidi i dokumente u: RUPIĆ, GEIGER, Partizanska i komunistička represija i zločini u Hrvatskoj, sv. 4.

116 Narodnooslobodilačka vojska i partizanski odredi Jugoslavije preimenovani su 1. ožujka 1945. u Jugoslavensku armiju. VODUŠEK STARIČ, Kako su komunisti osvojili vlast, 221. 
konvencija, kojima je NDH službeno pristupila 13. ožujka 1943. ${ }^{117}$ Međutim, situacija na terenu bila je drugačija, a sredinom svibnja 1945. zarobljeni pripadnici oružanih snaga i civili izručeni su postrojbama Jugoslavenske armije. Neosporna je činjenica da odgovornost za zločine nakon izručenja snose britanske vojne vlasti, koje su zarobljenike na prijevaru ustupile jedinicama Jugoslavenske armije iako je još 30. travnja britanski premijer Churchill naglasio da „antipartizanske snage treba razoružati i smjestiti u izbjegličke logore”, a s time su se 2 . svibnja složile i američke vojne vlasti. ${ }^{118}$ Tim su postupcima Britanci kršili međunarodno ratno pravo jer je položaj ratnih zarobljenika proizlazio iz Ženevske konvencije o postupanju s ratnim zarobljenicima (1929.) i vrijedio je do dobrovoljne repatrijacije, a nasilna repatrijacija bila je strogo zabranjena. Usprkos tome britanske su vojne vlasti u Austriji, a tako i pripadnici Jugoslavenske armije, grubo prekršili tri uvodna članka Haaških regulacija koja su dodana IV. Haaškoj konvenciji iz 1907., zatim članke 1.-5., 9., 11.-15., 17., 25.-27. i 29. Ženevske konvencije o poboljšanju sudbine ranjenih $i$ bolesnih pripadnika oružanih snaga na bojnom polju te članke 1.-8., 11., 18., 25., 26., 36., 45., 46., 52., 54., 56., 61., 62., 66., 76., 77., 81., 82. i 89. Ženevske konvencije o postupanju s ratnim zarobljenicima, koje je Jugoslavija potpisala 1931. godine. ${ }^{119}$ Položaj poražene strane čije oružane snage nisu bile priznata zaraćena strana regulirao je 1. članak Ženevske konvencije o postupanju s ratnim zarobljenicima, koji se odnosio na 1., 2. i 3. članak Haaških regulacija (1907.), na temelju kojih se međunarodno ratno pravo primjenjivalo na dobrovoljačke odrede i vojnicu, a u zemljama u kojima su te postrojbe sačinjavale oružane snage upotrebljavao se termin „vojska”, pa su imali pravo na postupak koji se primjenjivao na ratne zarobljenike. ${ }^{120}$ Međutim, jedinice Jugoslavenske armije nisu se obazirale na odredbe međunarodnoga ratnog prava. Idući problem koji se nastavljao na prethodne prekršaje međunarodnih normi bio je tretman koji su jugoslavenski represivni organi primjenjivali na takve zarobljenike. Iako su službena jugoslavenska glasila pisala o (ratnim) zarobljenicima, ostalo je nejasno jesu li takav tretman imali i pripadnici poraženih snaga NDH i drugih protukomunističkih (srpskih, slovenskih, crnogorskih...) jedinica, a razrješenju dvojbe može pomoći i jedno opravdanje strogoga tretmana domobrana koje je iznio Vladimir Bakarić, sekretar Centralnoga komiteta Komunističke partije Hrvatske (CK KPH) i predsjednik Narodne vlade Federalne Hrvatske. Naime, u izvješću o prilikama u Hrvatskoj koje je sastavio 27. srpnja 1945. britanski diplomatski predstavnik u Jugoslaviji Ralph Stevenson prenio je Ba-

117 Švicarske savezne vlasti 13. ožujka 1943. okružnicom su izvijestile vlade država potpisnica Ženevskih konvencija o pristupanju NDH temeljnim dokumentima međunarodnoga ratnog prava. Više u: KEVO, „Imenovanje stalnog predstavnika”, 227-228.

118 BEKIĆ, „Slučaj Bleiburg”, 200. Sažeto o izručenju zarobljenika: GRAHEK RAVANČIĆ, „Izručenja zarobljenika s bleiburškog polja i okolice u svibnju 1945.”, 531-550; GRAHEK RAVANČIĆ, „Izručenja i sudbine zarobljenika smještenih u savezničkim logorima u svibnju 1945.", 391-417.

119 NDH: Ministarstvo vanjskih poslova. Međunarodni ugovori 1943., 6-16, 19-44.

${ }^{120}$ Isto, 19. 
karićev navod da se radilo o 40 do 50 tisuća zarobljenih domobrana, odnosno osoba smještenih u logore koje su „ratni zločinci, a ne obični vojni ratni zarobljenici”. ${ }^{121}$ Čini se da su domobrani tretirani kao politički zatvorenici, odnosno istovjetno kako su za vrijeme rata vlasti NDH tretirale zarobljene pripadnike NOV i POJ, budući da su jugoslavenske vlasti odbacivale bilo kakvu intervenciju u korist domobrana jer se, navodno, radilo o unutarnjem pitanju suverene i međunarodno priznate države. Usprkos očitom položaju posljednje kategorije ratnih stradalnika koji nisu uživali zaštitu međunarodnoga ratnog prava, zanimljivo je da su u više napisa objavljenih u zagrebačkom Vjesniku iznesene tvrdnje da se s domobranima postupa kao s ratnim zarobljenicima od dana njihova zarobljavanja. ${ }^{122}$ Štoviše, u Vjesniku je nešto kasnije objavljen i članak, koji se lako može okarakterizirati kao promidžbeni tekst, u kojem se kategorički tvrdi da se prema domobranskim časnicima i dočasnicima u Maksimiru postupa u skladu s međunarodnim ratnim pravom. ${ }^{123}$ Iako se Maksimir ne spominje kao zarobljenički logor nego „sabiralište”, iz teksta je jasno da se radilo o logoru za ratne zarobljenike. ${ }^{124}$ Premda su zarobljeni pripadnici ustaško-domobranskih snaga tretirani kao politički zatvorenici, ima naznaka da se i na njih, osobito na domobrane, namjeravalo primijeniti neke propise Ženevskih konvencija. U zahtjevu se to izrijekom ne navodi, ali izvjesno je da je Ivan Krajačić Stevo sredinom srpnja 1945. zatražio da se osigura korespondencija zarobljenih domobrana s obiteljima. ${ }^{125}$ Nesumnjivo se radilo o djelomičnom popravljanju lošega odnosa prema zarobljenicima, ali postoji i mogućnost da su prijedlozi bili posljedica stalnoga pritiska MOCK-a da se vlasti pridržavaju međunarodno preuzetih obveza budući da je osobna korespondencija zarobljenika s njihovim obiteljima bila jedan od najvažnijih aspekata rada MOCK-a. Ako su prijedlozi bili tek posljedica međunarodnih pritisaka, očito je da su jugoslavenske vlasti međunarodno ratno pravo primjenjivale selektivno i prihvaćale, odnosno primjenjivale odredbe koje su se činile benignima, a sustavno kršile druge, mnogo važnije odredbe Ženevskih konvencija.

Nakon prihvaćanja Zakona o pomilovanju i amnestiji te Ukaza od 3. kolovoza 1945. dio zarobljenih pripadnika vojnih snaga NDH otpušten je kućama. ${ }^{126}$ Čini se da se to odnosilo samo na domobrane jer su na sjednicama CK KPH jedino oni označavani pojmom „zarobljenici”. Ostali zarobljenici, odnosno ratni zarobljenici i pripadnici raznih narodnosnih skupina koji su bili osumnjičeni za suradnju s neprijateljem, bili su u saveznoj nadležnosti, a sredinom rujna 1945. iskazana je potreba da se u Hrvatskoj izgradi smještaj

121 SPEHNJAK, Britanski pogled na Hrvatsku, 253, bilj. 48.

122 „Mačekova 'domobranska politika”, Vjesnik (Zagreb), 7. 7. 1945., 1.

123 „U maksimirskom sabiralištu domobranskih oficira i podoficira”, Vjesnik (Zagreb), 2. 8. 1945., 5 .

124 Isto.

125 „Zapisnik sa sjednice CK KPH održane 18. VII. 1945. godine u Zagrebu”, u: VOJNO-

VIĆ, Zapisnici Politbiroa Centralnoga komiteta Komunističke partije Hrvatske, sv. 1, 72.

126 „Ukaz Predsjedništva AVNOJ-a o općoj amnestiji i pomilovanju”, u: DIZDAR et al., Partizanska i komunistička represija i zločini u Hrvatskoj. Dokumenti, 237-239. 
za 34 tisuće zarobljenika. Iako je iz zapisničkoga navoda opet nejasno o kojim se to zarobljenicima raspravljalo, tj. je li se radilo o novim zarobljenicima, o ukupnom broju zarobljenika ili o zarobljenicima nakon provedenoga postupka amnestije, izgleda da se radilo o okvirnom broju zarobljenika u Hrvatskoj jer ih se krajem 1945. spominje oko 35 tisuća. ${ }^{127} \mathrm{U}$ izvješću Odjela za ratne zarobljenike Ministarstva narodne odbrane Federativne Narodne Republike Jugoslavije od 26. veljače 1946. stoji da je po oslobođenju Jugoslavije zarobljeno 114415 jugoslavenskih državljana koji su „služili u nemačkoj i kvislinškim vojskama”, od čega je 55 tisuća domobrana prevedeno u radne bataljune Jugoslavenske armije, a oko 41 tisuća ljudi amnestirana je po ukazu od 3. kolovoza 1945., pa bi se moglo pretpostaviti da je prije spomenut broj označavao ukupan broj zarobljenika u Hrvatskoj krajem 1945. godine. ${ }^{128}$ Međutim, ovdje treba spomenuti i izvješće o „ratnim zarobljenicima” koje je 17. rujna 1945. Središnjoj agenciji za ratne zarobljenike MOCK-a uputio dr. François Jaeggy, stalni predstavnik MOCK-a u Jugoslaviji. Osim ponovljenih uvjeravanja jugoslavenskih vlasti da će se pridržavati odredaba Ženevskih konvencija iz 1929. zanimljivim se čini i navod Središnjega komesarijata za ratne zarobljenike da se tada u Jugoslaviji nalazilo oko 200 tisuća ratnih zarobljenika, od kojih su polovica, odnosno njih oko 100 tisuća, kako to navodi dr. Jaeggy, bili „domobrantzi” (snage NDH), „oustachi” (Pavelićeva milicija) te „Tchétnitzi” (ljudi D. Mihailovića). ${ }^{129}$

O tretmanu zarobljenika treba dodati još nekoliko detalja. ${ }^{130}$ Premda je još 24. travnja 1945. predstavnik MOCK-a iz Bugarske u Ženevu brzojavio poruku zaprimljenu od dr. Rudolfa Vögelija, stalnoga predstavnika MOCK-a u Beogradu, da su jugoslavenske vlasti odobrile slanje pomoći ratnim zarobljenicima te započele otvaranje službenoga Obavještajnog ureda (Bureau officiel renseignements) za potrebe ratnih zarobljenika, što im je bila obveza na temelju 77. članka Ženevske konvencije o postupanju s ratnim zarobljenicima, o broju ratnih zarobljenika u Jugoslaviji moglo se tek nagađati. ${ }^{131}$ Vlasti su u početku odbijale popustiti zahtjevima stranih diplomatskih predstavnika ili predstavnika humanitarnih organizacija poput MOCK-a, a nastojale su potpuno marginalizirati ulogu Međunarodnoga odbora u tim pitanjima tvrdeći da se radi o unutarnjim pitanjima Jugoslavije. Takve tvrdnje nisu imale uporišta u međunarodnom pravu, ali ni u međunarodnim ugovorima čiji je potpisnik bila

127 „Zapisnik sa sjednice CK KPH održane 21. septembra 1945. godine u Zagrebu” i „Zapisnik sa sjednice biroa CK KPH održane dana 28. XII. 1945. godine u Zagrebu", u: VOJNOVIĆ, Zapisnici Politbiroa Centralnoga komiteta Komunističke partije Hrvatske, sv. 1, 119, 160.

${ }_{128}$ DIZDAR et al., Partizanska i komunistička represija i zločini u Hrvatskoj. Dokumenti, 313-314.

${ }_{129}$ CH-ACICR, G. 6/II, Application convention G-Z, Fasc. Yougoslavie. Izvješće od 17. 9. 1945., 1.

${ }^{130}$ O položaju i tretmanu ratnih zarobljenika postoji veoma opsežna bibliografija. Uz spomenute bibliografske jedinice u tekstu vidi primjerice i: RODINIS, Velika praznina; TROHA, „Italijani v vojnem ujetništvu v Jugoslaviji 1944-1947”; ДИМИЋ, „НН обнови Југославије радимо за Немачку" і tamo navedenu literaturu.

${ }_{131}$ CH-ACICR, G. 10/139 - Yougoslavie, Brzojav iz Sofije od 24. 4. 1945. 
i jugoslavenska strana. Međutim, jugoslavensko gledište treba promatrati kroz prizmu obračuna s poraženom stranom, jer ni u jednoj pobjedničkoj državi nakon kapitulacije njemački ratni zarobljenici nisu stradali kao u Jugoslaviji. Prema istraživanjima Vladimira Geigera, od 194 tisuće ratnih zarobljenika koliko ih je bilo u Jugoslaviji njih 80 do 100 tisuća izgubilo je život, a u taj broj nisu bili ubrojeni njemački vojnici zarobljeni u borbama i likvidirani „odmah na licu mjesta”. ${ }^{132}$ S obzirom na izložene podatke, jasnije je zašto su jugoslavenske vlasti i sama Jugoslavenska armija odbijale upletanje predstavnika stranih organizacija ili diplomatskih predstavnika u pitanja u vezi s (ratnim) zarobljenicima. Na temelju spomenutoga brzojava iz Sofije, tj. odluke jugoslavenskih vlasti o otvaranju Obavještajnoga ureda za ratne zarobljenike, u vodstvu MOCK-a vjerovali su da će se jugoslavenske vlasti pridržavati normi međunarodnoga ratnog prava jer im nije trebalo zaoštravanje odnosa na vanjskopolitičkom planu. Međutim, stvarni odnos prema odredbama kao i prema ratnim zarobljenicima ilustriraju podaci da je Tito 3. svibnja 1945. izdao naredbu da se osnuje Odjel za ratne zarobljenike Generalštaba Jugoslavenske armije, ali naredba da svaka armija ustroji Odjel za ratne zarobljenike izdana je tek 30. lipnja 1945., čemu je prethodilo Organizacijsko izvješće III. odsjeka OZNA-e za Hrvatsku o ustrojavanju Štaba za (ratne) zarobljenike koje je načelniku OZNA-e upućeno tek 16. lipnja. ${ }^{133}$ Premda je to bila obveza vojnih vlasti koja je proizlazila iz Ženevske konvencije o postupanju s ratnim zarobljenicima, zanimljivo je da je od osnivanja pri Generalštabu do osnivanja po pojedinim armijama prošlo oko dva mjeseca, što je bilo vrijeme planski počinjenih zločina u svibnju i lipnju 1945., prije svega u Sloveniji, a potom i kao posljedica samovoljnoga postupanja zapovjednika pojedinih jedinica Jugoslavenske armije. ${ }^{134}$

\section{Zaključne napomene}

Rad MOCK-a u korist ratnih stradalnika do izražaja dolazi u ratnim okolnostima, a temeljio se na međunarodnom ratnom pravu (Ženevske i Haaške konvencije) koje je bilo normirano samo za službeno priznate pripadnike oružanih snaga zaraćenih strana. Nakon vojnoga sloma Kraljevine Jugoslavije sredinom 1941. Komunistička partija Jugoslavije pozvala je 22. lipnja 1941. na antifašističku borbu te započela s osnivanjem partizanske vojske koja će se suprotstaviti silama Osovine. Iako je MOCK znao za postojanje partizanskih jedinica, podaci o njima bili su nepouzdani, ali na osnovi načela izbjegavanja konfrontacija MOCK je pokušao uspostaviti kontakte s partizanima da $u$

132 GEIGER, Nestanak folksdojčera, 60. O odnosu prema njemačkim ratnim zarobljenicima u Jugoslaviji usp. BÖHME, Zur Geschichte der Deutschen Kriegsgefangenen des Zweiten Weltkrieges, Band I/1; BÖHME, Zur Geschichte der Deutschen Kriegsgefangenen des Zweiten Weltkrieges, Band I/2.

133 DIZDAR et al., Partizanska i komunistička represija i zločini u Hrvatskoj. Dokumenti, 165-166. Usp. i: JAREB, „Titove naredbe o hrvatskim ratnim zarobljenicima”, 609-618.

134 VODUŠEK STARIČ, Kako su komunisti osvojili vlast, $260 \mathrm{i}$ d. 
krug zaraćenih strana koje su poštovale međunarodno ratno pravo uključi što više sukobljenih strana. Vodstvo MOCK-a započelo je i akciju da se odredbe u korist ratnih zarobljenika prošire i na civile, ali to su vlasti Njemačkoga Reicha odbile, što je bio stav i vlasti NDH, te su partizani tretirani kao „civili uhvaćeni kao ratni zarobljenici”, odnosno kategorija stradalnika koja nije uživala zaštitu normiranoga ratnog prava i bila je unutarnje pitanje svake pojedine države.

Nakon imenovanja J. Schmidlina ml. na mjesto stalnoga predstavnika u Zagrebu (1943.) MOCK se osobito počeo zanimati za „partizansko” pitanje, a njegov se rad svodio na pokušaje da se partizanima prizna položaj zaraćene strane. To je bilo izgledno jer su udovoljavali Haaškim regulacijama, a tome su pogodovali i njemačko-partizanski pregovori. Stoga se Schmidlin osobito angažirao da se pripadnicima NOV i POJ prizna službeni položaj zaraćene strane, pa je od kraja travnja 1943. intervenirao u nadležnim ministarstvima NDH, poslije i kod predsjednika Vlade NDH Nikole Mandića, kod Središnjega ureda HCK-a i viđenijih osoba političkoga i društvenoga života. Međutim, iako su partizani u odnosima s njemačkim vojnim snagama de facto ostvarili položaj zaraćene strane, vlasti NDH tome su se oštro protivile.

Uslijed promjene britanskoga stava o partizanima vodstvo MOCK-a naložilo je stalnom predstavniku u Zagrebu da s njima što je prije moguće stupi u kontakt. Bila je to i posljedica saznanja da se u njemačkim koncentracijskim logorima u Norveškoj na prisilnom radu nalaze zarobljeni pripadnici Narodnooslobodilačke vojske Jugoslavije koji su tretirani kao politički zatvorenici. Schmidlin je stupio u kontakt s Vrhovnim štabom Narodnooslobodilačke vojske Jugoslavije s upitima hoće li se pridržavati međunarodnoga ratnog prava, a tražio je i da se primjena proširi na internirane civile, da se prihvati stalni predstavnik MOCK-a te odobrenje da se na oslobođena područja šalje pomoć za civile.

Nakon početka Teheranske konferencije savezničkih vođa vodstvu MOCK-a upućena je 29. studenog 1943. iz Londona pismena sugestija da započne pregovore o uspostavi službenih odnosa s partizanima. Na te prijedloge Vrhovni štab Narodnooslobodilačke vojske Jugoslavije očitovao se tek krajem siječnja 1944., ali budući da su partizanski predstavnici izbjegavali predložene pregovore, odnosno izbjegavali predstavnike MOCK-a u Italiji, pregovori su ubrzo obustavljeni. Bez odgovora jugoslavenskih partizana na iznijete prijedloge vodstvu MOCK-a bile su vezane ruke i u pokušajima da im se prizna položaj zaraćene strane jer njegovi predstavnici u kontaktima s njemačkom stranom nisu mogli jamčiti da će partizani u odnosu prema zarobljenim pripadnicima njemačkih snaga primjenjivati temeljno načelo reciprociteta. Usprkos tom neuspjehu MOCK je 17. kolovoza 1944. zaraćenim državama uputio memorandum o postupanju sa sukobljenom stranom kojoj nisu bila priznata prava i položaj zaraćene strane koji se odnosio na jugoslavenske partizane.

Uspostavljanje službenih odnosa otežavalo je i istodobno postojanje izbjegličkoga JOCK-a u Londonu, koji je imao legitimitet i bio jedino priznato na- 
cionalno društvo Crvenoga križa, a vodstvo MOCK-a ostalo je pri odluci o nepriznavanju novih društava nastalih u ratnim okolnostima. Do promjene dolazi nakon potpisivanja sporazuma Tito-Šubašić, kad je ubrzan razvoj mreže lokalnih ogranaka Crvenoga križa na području pod kontrolom Narodnooslobodilačke vojske Jugoslavije, što je bio jedan od preduvjeta za uspostavu službenih odnosa. Krajem rujna i početkom listopada 1944. Stalnom predstavništvu MOCK-a u Londonu obratili su se predstavnici izbjegličke vlade dr. Šubašića, ali i maršala Tita, upoznajući ih s time da je osnovan Središnji odbor Jugoslavenskoga Crvenoga križa na otoku Visu, a izbjeglički JOCK u Londonu raspušten je 6. listopada 1944., čime je dovršen postupak ujedinjavanja nacionalne organizacije Crvenoga križa. To je vrlo brzo rezultiralo uspostavom službenih odnosa između MOCK-a i NKOJ-a.

Nakon uspostave službenih odnosa MOCK je započeo opsežnu aktivnost u korist ratnih stradalnika na područjima pod kontrolom partizana. Osim raznih oblika pomoći, MOCK se pred kraj rata i u neposrednom poraću osobito angažirao da se praktična primjena odredaba međunarodnoga ratnog prava primijeni i na ratne zarobljenike u Jugoslaviji. Takva je obećanja dao i Tito, iako je jugoslavensko Ministarstvo socijalne politike to uvjetovalo time da se dokaže da se na istovjetan način postupalo sa zarobljenim pripadnicima NOV i POJ za vrijeme rata. O tretmanu zarobljenika u Jugoslaviji moglo se samo nagađati, a vlasti su u neposrednom poraću odbijale da strani diplomatski predstavnici ili predstavnici MOCK-a dobiju uvid u tretman (ratnih) zarobljenika tvrdeći da se radi o unutarnjem pitanju Jugoslavije. Iz toga je vidljivo da je MOCK za vrijeme rata nailazio na istovjetne probleme bilo da se radilo o vlastima NDH, Njemačkoga Reicha ili pak jugoslavenskim vlastima na kraju rata i u neposrednom poraću.

\section{Arhivsko gradivo}

CH-ACICR: Confédération Helvétique, Archives du Comité international de la Croix-Rouge, Genève, Archives générales 1918-1950:

- CH-ACICR, CR: Sous-groupe CR/00 Relations avec les Sociétés nationales 1916-1951 (Sociétés nationales de la Croix-Rouge et du Croissant-Rouge, 1917-1954):

- 00/52 - Serbie (puis) Yougoslavie, 21. 12. 1918. - 31. 12. 1950.

- 196 - Serbie (puis Yougoslavie), II., 20. 3. 1934. - 6. 11. 1950.

- 00/73 - Croatie.

- 244 - Croatie: Croix-Rouge croate à Zagreb, 13. 12. 1918. - 24. 4. 1946.

- CH-ACICR, G.: Groupe G: Généralités: affaires opérationnelles 19391950:

- CH-ACICR, G. D EUR YOUG 1: Délégation Belgrade 1939-1950, Autorités Croix-Rouge Yougoslave Correspondance.

- CH-ACICR, G. 3/00: Service des Délégations, 1939-1950. 
- CH-ACICR, G. 3: Missions, Délégations, 1939-1950.

- 3/66 - Yougoslavie - Mooser, décembre 1944 - avril 1945.

- CH-ACICR, G. 6: Application des Conventions, Extension des Conventions, 1939-1951.

- CH-ACICR, G. 10: Bureaux nationaux de renseignements et transmission de listes nominatives de PG et IC, 1939-1950.

- 10/139 - Yougoslavie, 1939-1950.

- CH-ACICR, G. 12: Méthodes et plans de travail du CICR (Agence Centrale du Prisonniers de la Guerre), 1940-1950.

- CH-ACICR, G. 17: Camps - Listes des effectifs - Courrier des Délégations CICR, 1939-1950.

- G. 17/00 - Généralités PG, septembre 1939 - juin 1947.

- G. 17/139 - Yougoslavie, 1939-1950.

- CH-ACICR, G. 21: Croix-Rouge sur territoires étrangères, 1939-1948.

- CH-ACCIR, G. 59: Israélites, 1939-1961.

- CH-ACICR, G. 59/2: Secours et questions de principe, 1940-1961.

- 2/151 - 15: Secours à la Croatie, 27. 4. 1943. - 18. 7. 1945.

- CH-ACICR, G. 85: Gouvernements, 1939-1950.

- Croatie, 1939-1950.

- Yougoslavie, 1939-1950.

- CH-ACICR, C G2 YU: $2^{\mathrm{e}}$ guerre mondiale - Service yougoslave 19411946:

- CH-ACICR, C G2 YU 13: Rapports div. re activités du serv. (Statistiques, PVs, etc.) (01011941-31121945).

- CH-ACICR, C G2 YU 39: Dossier re marche du serv. (Rapports et statistiques div.) (01011941-31121946).

- CH-ACICR, C G2 YU 45: GEN re camps (effectifs, assistance, courrier, etc.) class./matière (art. 67-68) (01011941-31121954).

- CH-ACICR, C G2 YU 51: Corresp. (nc) in/out avec représentations diplomatiques YU ds le monde class./représentant (0101194131121946).

- CH-ACICR, C G2 YU 52: Corresp. (nc) in/out re Partisans class. chrono (01011943-31121945).

- CH-ACICR, B SEC DAS: Division d'assistance spéciale [Special Relief Division], 1940-1963:

- ZA: Correspondance générale:

- 28 - Délégation du CICR en Yougoslavie [y compris Croatie]: [correspondance générale], 3. 7. 1943. - 27. 2. 1945.

- 28.01 - Délégation du CICR à Belgrade, 3. 7. 1943. - 27. 2. 1945.

- 28.02 - Délégation du CICR à Zagreb, 11. 4. 1944. - 21. 2. 1945. 
- CH-ACICR, APCICR: Archives du personnel du Comité International de la Croix-Rouge:

- 1. GALLOPIN, dr. Roger.

HR-DAVŽ-0019-ONOO Varaždin: Hrvatska, Državni arhiv u Varaždinu, Varaždin, fond 0019, Okružni narodnooslobodilački odbor Varaždin (1943. - 1945.).

\section{Objavljeni izvori i tisak}

BEGIĆ, Miron Krešimir. Nezavisna Država Hrvatska: ljetopis 1941. 1945. Split: Naklada Bošković, 2007.

BROWN SCOTT, James, ur. The Geneva Convention of 1906 for the Amelioration of the Condition of the Wounded in Armies in the Field. Washington, D. C., 1916.

BROWN SCOTT, James, ur. The Hague Conventions and Declarations of 1899 and 1907 accompanied by Tables of Signatures, Ratifications and Adhesions of the Various Powers, and Texts of Reservations. New York; Washington, D. C., 1915.

CHAPUISAT, Edouard. Le Comité international de la Croix-Rouge et les déportés [strojopis; rukopis]. Genève, 24. 12. 1946. CICR: Centre d'information et de Documentation - Bibliothèque, sig. 362.191/1042(Br.).

CHAPUISAT, Edouard. Les homes et les faits: Le Comité international de la Croix-Rouge et les Israélites [strojopis; rukopis]. Genève, 1945. CICR: Centre d'information et de Documentation - Bibliothèque, sig. 362.191/043(Br.).

"Constitution et situations particulières des Sociétés de Croix-Rouge en temps de guerre". Bulletin International des Sociétés de la Croix-Rouge (Genève) 72 (Septembre 1941), No. 469: 763-767.

"Convention Relating to the Treatment of Prisoners of War". The American Journal of International Law 27 (1933), No. 2, Supplement: Official Documents: 59-91.

„Geneva Convention Relative to the Treatment of Prisoners of War”. The American Journal of International Law 47 (1953.), No. 4, Supplement: Official Documents: 119-177.

DIZDAR, Zdravko; GEIGER, Vladimir; POJIĆ, Milan; RUPIĆ, Mate, prir. Partizanska i komunistička represija i zločini u Hrvatskoj 1944. - 1946. Dokumenti. Slavonski Brod: Hrvatski institut za povijest, Podružnica za povijest Slavonije, Srijema i Baranje, 2005.

Documents sur l'activité du Comité international de la Croix-Rouge en faveur des civils détenus dans les camps de concentration en Allemagne (19391945). Genève: CICR, 1947.

GEIGER, Vladimir. prir. Partizanska i komunistička represija i zločini u Hrvatskoj 1944. - 1946. Dokumenti, sv. 2: Slavonija, Srijem i Baranja. Slavon- 
ski Brod: Hrvatski institut za povijest, Podružnica za povijest Slavonije, Srijema i Baranje, 2006.

GEIGER, Vladimir; RUPIĆ, Mate; KEVO, Mario; KRALJEVIĆ, Egon; DESPOT, Zvonimir, prir. Partizanska i komunistička represija i zločini u Hrvatskoj 1944. - 1946. Dokumenti, sv. 3: Zagreb i središnja Hrvatska. Slavonski Brod; Zagreb; Hrvatski institut za povijest, Podružnica za povijest Slavonije, Srijema i Baranje; Hrvatski institut za povijest, 2008.

Geneva Conventions for the Protection of War Victims. Report of the Committee of the Foreign Relations: Executive Report No. 9. Washington: Senate, United States Government Printing Office, 1955.

Inter Arma Caritas: The Work of the International Committee of the Red Cross during the Second World War. Geneva: International Committee of the Red Cross, 1947.

KEVO, Mario, prir. Veze Međunarodnog odbora Crvenog križa i Nezavisne Države Hrvatske, sv. I. Slavonski Brod; Zagreb; Jasenovac: Hrvatski institut za povijest, Podružnica za povijest Slavonije, Srijema i Baranje; Hrvatski državni arhiv; Javna ustanova Spomen-područje Jasenovac, 2009.

Les Conventions de Genève de 1929. Extrait du Manuel de la Croix-Rouge internationale. Genève: CICR, s. a.

MILETIĆ, Antun. Koncentracioni logor Jasenovac 1941-1945. Dokumenta, knj. I-II. Beograd: Narodna knjiga i Spomen-područje Jasenovac, 1986.

NDH: Ministarstvo vanjskih poslova. Međunarodni ugovori 1941. - 1943. Zagreb, s. a.

Rapport du Comité International de la Croix-Rouge sur son activité pendant la seconde guerre mondiale (1 ${ }^{\text {er }}$ septembre 1939 - 30 juin 1947), vol. III: Actions de Secours. Genève: CICR, Juin 1948.

Report of the International Committee of the Red Cross on its activities during the Second World War (September 1, 1939 - June 30, 1947), vol. I: General Activities. Geneva: ICRC, May 1948.

Report of the International Committee of the Red Cross on its activities during the Second World War (September 1, 1939 - June 30, 1947), vol. II: The Central Agency for Prisoners of War. Geneva: ICRC, May 1948.

Report of the Joint Relief Commission of the International Red Cross 19411946. Geneva: International Red Cross Committee and League of Red Cross Societies, 1948.

Revue Internationale de la Croix-Rouge (Genève), 1941-1945.

RUPIĆ, Mate; GEIGER, Vladimir, prir. Partizanska i komunistička represija i zločini u Hrvatskoj 1944. - 1946. Dokumenti, sv. 4: Dalmacija. Slavonski Brod; Zagreb: Hrvatski institut za povijest, Podružnica za povijest Slavonije, Srijema i Baranje; Hrvatski institut za povijest, 2011.

The Work of the ICRC for Civilian Detainees in German Concentration Camps (1939-1945). Geneva: ICRC, 1947. 
VELEBIT, Vladimir. Sjećanja. Zagreb: Globus, 1983.

Vjesnik jedinstvene Narodno oslobodilačke fronte Hrvatske (Zagreb), 1945.

VOJNOVIĆ, Branislava, prir. Zapisnici Politbiroa Centralnoga komiteta Komunističke partije Hrvatske 1945. - 1952., sv. 1: 1945. - 1948. Zagreb: Hrvatski državni arhiv, 2005.

\section{Literatura}

ABPLANALP, Philippe. „The International Conferences of the Red Cross as a Factor for the Development of International Humanitarian Law and the Cohesion of the International Red Cross and Red Crescent Movement". International Review of the Red Cross (Geneva) 308 (1995): 520-549.

BARBIĆ, Mate. „Jugoslavenski zbjeg u južnoj Italiji i Egiptu (1943-1946)”. Zbornik Instituta za historiju radničkog pokreta Dalmacije 3 (1975): 797-807.

BARKER, Elisabeth. Britanska politika na Balkanu u II. svjetskom ratu, sv. I-II. Zagreb; Ljubljana: Globus, 1978.

BEKIĆ, Darko. „Slučaj Bleiburg': nova istraživanja, nova iskušenja”. Časopis za suvremenu povijest 21 (1989), br. 1-3: 197-214.

BLUMENWITZ, Dieter. Okupacija in revolucija $v$ Sloveniji (1941-1946). Mednarodnopravna študija. Celovec: Mohorjeva založba, 2005.

BOBAN, Ljubo. Hrvatske granice 1918-1993. Zagreb: Školska knjiga, 1993.

BÖHME, Kurt W. Zur Geschichte der Deutschen Kriegsgefangenen des Zweiten Weltkrieges, Band I/1: Die deutschen Kriegsgefangenen in Jugoslawien 1941-1949. Bielefeld: Verlag Ernst und Werner Giesking, 1962.

BÖHME, Kurt W. Zur Geschichte der Deutschen Kriegsgefangenen des Zweiten Weltkrieges, Band I/2: Die deutschen Kriegsgefangenen in Jugoslawien 1949-1953. Bielefeld: Verlag Ernst und Werner Giesking, 1976.

BRATANIĆ, Mateo. „Hrvatski zbjegovi u Italiji od 1943. do 1945. godine”. Časopis za suvremenu povijest 48 (2016), br. 1: 161-196.

BUGNION, François. The International Committee of the Red Cross and the Protection of War Victims. Geneva: ICRC \& Macmillan Publishers, 2003.

DE SANTIS, Hugh. „In Search of Yugoslavia: Anglo-American Policy and Policy-making 1943-45”. Journal of Contemporary History 16 (1981), br. 3: 541-563.

ДИМИЋ, Наталија. „На обнови Југославије радимо за Немачку’: немачки заробљеници, антифашисти, пропагандисти”. Токови историје 2 (2020): 75-105.

DIZDAR, Zdravko. „Brojidbeni pokazatelji odnosa vojničkih postrojbi na teritoriju Nezavisne Države Hrvatske 1941. - 1945. godine”. Časopis za suvremenu povijest 28 (1996), br. 1-2: 161-197.

DJUROVIĆ, Gradimir. The Central Tracing Agency of the International Committee of the Red Cross. Geneva: Henry Dunant Institute, 1986. 
FORSYTHE, David P. „The Red Cross as Transnational Movement: Conserving and Changing the Nation-State System". International Organization 30 (1976), br. 4: 607-630.

GEIGER, Vladimir. Nestanak folksdojčera. Zagreb: Nova stvarnost, 1997.

GEIGER, Vladimir; LEČEK, Suzana. „Politika retribucije u Europi nakon Drugoga svjetskog rata”. Časopis za suvremenu povijest 50 (2018), br. 1: 7-34.

GRAHEK RAVANČIĆ, Martina. „Izručenja i sudbine zarobljenika smještenih u savezničkim logorima u svibnju 1945.” Časopis za suvremenu povijest 41 (2009), br. 2: 391-416.

GRAHEK RAVANČIĆ, Martina. „Izručenja zarobljenika s bleiburškog polja i okolice u svibnju 1945." Časopis za suvremenu povijest 39 (2007), br. 3: 531-550.

HUBER, Max. Principles and Foundations of the Work of the International Committee of the Red Cross, 1939-1946. Geneva: ICRC, 1947.

JAKOVINA, Tvrtko. Američki komunistički saveznik: Hrvati, Titova Jugoslavija i Sjedinjene Američke Države. Zagreb: Profil; Srednja Europa, 2003.

JAREB, Jere. „Titove naredbe o hrvatskim ratnim zarobljenicima i uništavanju hrvatskih domovinskih pobunjenika od 30. lipnja 1945. do 2. ožujka 1946." Hrvatska revija (München; Barcelona) 39 (1989), br. 3: 609-618.

JOKSIMOVIĆ, Sekula. „Narodnooslobodilački pokret Jugoslavije kao ratujuća strana i razmena zarobljenika u 1942. godini”. Vojnoistorijski glasnik XXXIV (1983), br. 1: 197-217.

JOKSIMOVIĆ, Sekula. „Narodnooslobodilački pokret Jugoslavije kao ratujuća strana i razmena zarobljenika u 1943. godini”. Vojnoistorijski glasnik XXXV (1984), br. 1: 95-117.

JONČIĆ, Vladan. Ratni zarobljenici, medunarodnopravni status. Beograd: Vojnoizdavački zavod, 2002.

KAZIMIROVIĆ, Vasa. NDH u svetlu nemačkih dokumenata i dnevnika Gleza fon Horstenau 1941-1944. Beograd: Nova knjiga; Narodna knjiga, 1987.

KEVO, Mario. „Imenovanje stalnog predstavnika Međunarodnog odbora Crvenog križa u Nezavisnoj Državi Hrvatskoj (1943.)”. Croatica Christiana Periodica XL (2016), br. 78: 209-234.

KEVO, Mario. „Neki aspekti rada Središnje agencije za ratne zarobljenike Crvenog križa u korist stradalnika s područja Nezavisne Države Hrvatske”. Časopis za suvremenu povijest 44 (2012), br. 3: 651-678.

KEVO, Mario; HERMAN KAURIĆ, Vijoleta. „Ženevske i Haaške konvencije u teoriji i praksi”. U: 1914. - Prva godina rata u Trojednoj Kraljevini i Austro-Ugarskoj Monarhiji. Zbornik radova, ur. Vijoleta Herman Kaurić. Zagreb: Matica hrvatska, 2018, 311-360.

KISIĆ KOLANOVIĆ, Nada. Mladen Lorković. Ministar urotnik. Zagreb: Golden marketing; Hrvatski državni arhiv, 1998. 
KISIĆ KOLANOVIĆ, Nada. NDH i Italija: političke veze i diplomatski odnosi. Zagreb: Naklada „Ljevak”; Hrvatski institut za povijest, 2001.

KRIZMAN, Bogdan. Pavelić između Hitlera i Mussolinija. Zagreb; Ljubljana: Globus, 1980.

LABOVIĆ, Đurica; BASTA, Milan. Partizani za pregovaračkim stolom 1941-1945. Zagreb: Naprijed, 1986.

LEDERMANN, Laszlo. „The International Organization of the Red Cross and the League of Red Cross Societies". The American Journal of International Law 42 (1948), br. 3: 635-644.

LEKOVIĆ, Mišo. Martovski pregovori 1943. Beograd: Narodna knjiga, 1985.

LOPIČIĆ-JANČIĆ, Jelena Đ. Krivičnopravna zaštita ratnih zarobljenika u jugoslovenskom krivičnom pravu. Beograd: Vaša knjiga, 2005.

MOREILLON, Jacques. Le Comité international de la Croix-Rouge et la protection des détenus politiques. Genève: Institut Henry-Dunant, 1973.

NEŠOVIĆ, Slobodan. Diplomatska igra oko Jugoslavije 1944-1945. Zagreb: Stvarnost, 1977.

PAVLICA, Dane, ur. Sto godina Crvenog križa u Slavonskoj Požegi. Slavonska Požega: Općinska organizacija Crvenog križa, 1988.

PLENČA, Dušan. Organizacija i evakuacija dalmatinskog zbjega preko otoka Visa (1943-1944). Posebni otisak iz Pomorskog zbornika, knj. 2. Zadar, 1964.

RODINIS, Andrej. Velika praznina. Njemački ratni zarobljenici na radu u Bosni i Hercegovini. Tuzla: Bosanska riječ, 2016.

SPEHNJAK, Katarina. Britanski pogled na Hrvatsku 1945. - 1948. Zagreb: Golden marketing - Tehnička knjiga, 2006.

TROHA, Nevenka. „Italijani v vojnem ujetništvu v Jugoslaviji 1944-1947”. Annales - series historia et sociologia 10 (2000), br. 2 (22): 325-340.

VODUŠEK STARIČ, Jera. Kako su komunisti osvojili vlast 1944. - 1946. Zagreb: Naklada P.I.P. Pavičić, 2006. 


\section{SUMMARY}

\section{The Establishment of Relations between the International Committee of the Red Cross and the People's Liberation Army and Partisan Detachments of Yugoslavia during World War II}

The active role of the International Committee of the Red Cross (ICRC) comes to the fore in wartime circumstances, in carrying out activities based on international war law (the Geneva and Hague Conventions) regarding providing assistance to all war victims. In securing working conditions during World War II, the ICRC attempted to establish official relations with all belligerent parties regardless of whether they were or were not recognised as belligerent parties. Therefore, the author presents part of the ICRC efforts made in the process of recognising the international war law-regulated status of belligerent party to members of the People's Liberation Army and Partisan Detachments of Yugoslavia, i.e. the status of prisoners of war. Despite some earlier contacts, after the designation of a permanent representative to the Independent State of Croatia (1943), the ICRC launched extensive activities in favour of members of the Yugoslav Partisan movement, the most important of which was the practical application of the international law of war. Permanent representative Schmidlin constantly intervened in the ministries and the prime minister of the Independent State of Croatia through the Central Office of the Croatian Red Cross and as well through prominent figures in the political and social life of the State. However, although the Partisans de facto achieved the position of a belligerent party in their relations with the German military forces, this status was strongly opposed by the ISC authorities.

Due to the change in the British attitude towards the Yugoslav Partisans, in the summer of 1943 the ICRC leadership ordered its permanent representative in Zagreb to establish contact with members of the People's Liberation Army of Yugoslavia as soon as possible. Very soon, Schmidlin contacted the Supreme Headquarters of the People's Liberation Army and Partisan detachments of Yugoslavia. In late November 1943, shortly after the beginning of the Allied Conference in Tehran, the ICRC leadership also received an Allied recommendation on the same subject. The existence of the Yugoslav Committee of the Red Cross in London, which had legitimacy and was the only recognised Yugoslav national Red Cross society, was a major problem in establishing relations between the ICRC and the Yugoslav Partisans. The ICRC leadership remained committed to not recognising the new societies created during the war. After the signing of the Tito-Šubašić agreement in mid-June 1944, the ICRC leadership changed its position, and representatives of the Yugoslav government and Marshal Tito sent several letters to the ICRC Permanent Delegation in London in late September and early October 1944. In those letters, they informed the ICRC leadership of the establishment of the Central Committee of the Yugoslav Red Cross on the island of Vis. At the same time, 
the Royal Yugoslav Red Cross Society in London was dissolved. All of this resulted in the unification of the national organisation of the Red Cross in Yugoslavia, which led to the establishment of official relations between the ICRC and Yugoslav Partisans at the end of 1944. Based on original archival sources and literature, the author points to some aspects of cooperation until the end of World War II and in the early post-war period. One of the main aspects of the ICRC's work during this period was the practical application of the provisions of the international law of war to prisoners of war in Yugoslavia. Tito himself made the same promises, though the Yugoslav Ministry of Social Policy made this conditional: they would be applied only if it was proven that captured members of the Partisan movement had been treated in the same way during the war. The treatment of prisoners of war in Yugoslavia could only be speculated about, and the authorities immediately refused to allow foreign diplomatic or ICRC representatives to gain insight into the treatment of prisoners of war. It is clear that the ICRC faced the same problems in its relations with the authorities of the Independent State of Croatia and the German Reich during the war and the Yugoslav authorities at the end of the war and in the immediate post-war period.

Key words: World War II; International Committee of the Red Cross (ICRC); Yugoslavia; Independent State of Croatia (ISC); People's Liberation Movement; People's Liberation Army and Partisan Detachments of Yugoslavia. 